\title{
Unlocking the genetic potential of chickpea through improved crop management practices in Ethiopia. A review
}

\author{
Lijalem Korbu $^{1} \cdot$ Bizuwork Tafes ${ }^{1} \cdot$ Girma Kassa $^{1} \cdot$ Tesfashbamlak Mola $^{2} \cdot$ Asnake Fikre $^{2}$ \\ Accepted: 16 March 2020 / Published online: 30 March 2020 \\ (C) INRAE and Springer-Verlag France SAS, part of Springer Nature 2020
}

\begin{abstract}
Chickpea (Cicer arietinum L.) production in Ethiopia is exclusively rainfed. The average national yield remains low comparing to the potentially attainable yield because of the common notion among producers that the crop does not need any nutrient inputs. The newly developed high-yielding cultivars have brought significant yield gains. However, their genetic potentials are still hampered by the traditional crop management practices used and the problematic Vertisol growing conditions. Yields of chickpea grown on Vertisols are limited by poor drainage when sown early and by drought when sown late. This calls for optimization of the balance with minimum tradeoffs in key economic traits. Here, we review research progress on chickpea over the past five decades in Ethiopia, with particular emphasis on crop management practices. The paper gives a comprehensive overview of research findings and information generated on the Vertisol cropping systems, where chickpea is the principal rotational crop under cereal-legume cultivation entailing substantial role in cropping system intensification. It has been noted that the productivity of Vertisol-grown chickpea is largely constrained more by lack of the use of best bet crop management practices than the genetics of a given cultivar. For instance, raised-bed method as compared to the conventional flatbed increased grain and biomass yields by about $74 \%$ and $58 \%$, respectively. The current average farm yield of chickpea in Ethiopia is about $55 \%$ of the yield potential of the crop, suggesting that farmers can still have rooms to substantially increase yield using improved practices. Based on the cumulative evidences, it can be concluded that the yield potentials of genetically elite cultivars may not be realized without synergistic combination of improved management practices and adequate nutrient use. We, therefore, recommend the integrated use of improved crop management strategies, while the soil physical properties still deserve utmost research attention.
\end{abstract}

Keywords Chickpea $\cdot$ Attainable yield potential $\cdot$ Crop management practices $\cdot$ Genetic potential $\cdot$ Vertisols

\section{Contents}

1. Introduction

2. Socio-economic significance of chickpea

3. Chickpea production bottlenecks in Ethiopia

4. Overview of Vertisol cropping systems

5. Crop diversification with chickpea: a necessity for sustainable Vertisol farming system

Lijalem Korbu

1korbu.balcha@gmail.com

1 Ethiopian Institute of Agricultural Research (EIAR), Debre Zeit Agricultural Research Center, Debre Zeit, Ethiopia

2 International Crops Research Institute for the Semi-Arid Tropics (ICRISAT), Addis Ababa, Ethiopia
6. Improved chickpea cultivars and their adaptation to Vertisol cropping systems

7. Advances and gaps in chickpea agronomy research in Ethiopia

7.1 Planting time

7.2 Planting density

7.3 The dilemma of fertilizer application on chickpea

7.4 Response of chickpea to $\mathrm{N}$ application

7.5 Response of chickpea to $\mathrm{P}$ application

7.6 Response of chickpea to organic fertilizer application

7.7 Chickpea response to Rhizobacterial inoculation

7.8 Response of chickpea to drainage methods

7.9 Prospects of chickpea cultivation using irrigation

8. Conclusions and future outlook

Acknowledgements

References 


\section{Introduction}

More than $80 \%$ of the Ethiopian population is dependent on agriculture, which accounts for about $50 \%$ of gross domestic product (GDP), $90 \%$ of the exports, and $85 \%$ of the employment (Tamene et al. 2017). This implies that investment in agricultural development can considerably contribute to food security and poverty reduction in the country. As a result, the Ethiopian government has placed agriculture at the center of its growth strategy, and declared improved productivity of smallholder farming system a policy priority (Headey et al. 2014; Fikre et al. 2018). On the other hand, the Ethiopian agriculture is dominated by rainfed system accounting for about $97 \%$ of current cropland area and generally regarded as low-yield system.

Grain legumes are the second most important crops in the national diet after cereals (Fikre 2016). Annually, legumes occupy on average about 1.3 million ha (12\%) of the total 11 million ha of land covered by different crops (CSA 19912018). Chickpea and common bean are the leading grain legumes in terms of foreign currency earnings, and they are well recognized as valuable sources of protein particularly for the under-privileged population. Chickpea (Cicer arietinum L.) is a self-pollinated annual crop which grows well in limited rainfall areas of the world (Singh et al. 2014). It is considered as one of the healthiest food grains, and its consumption contributes to healthy lifestyles (Jukanti et al. 2012). Moreover, chickpea serves as a disease break and fertility restorer crop in the cereal-dominated cropping systems in many countries where it is critical for both smallholder farmers and consumers (Fikre et al. 2018; Verkaart et al. 2017).

In Ethiopia, chickpea is an important food legume crop ranking third and seventh in the world in terms of yield and production, respectively (Korbu et al. 2016), and it accounts for over $90 \%$ of grain production in SSA (Verkaart et al. 2017). Importantly, it is among the principal legumes in the highland Vertisols mainly in the tef, wheat, and sorghumbased cropping systems (Fig. 1). Chickpea can grow well in elevation range of 1500 and $2700 \mathrm{~m}$. Economic yield, however, is obtained within an altitude range of 1700-2600 m. The crop is largely confined to the central and northern highlands of the country. Recently, the southern and southwestern highlands are also becoming potential niches (Beyene et al. 2015; Nigussie 2018).

Production of chickpea in Ethiopia over the last two decades showed an increasing trend regardless of the static nature of area under cultivation (Fig. 2a). Currently, the average national yield is close to $2000 \mathrm{~kg} \mathrm{ha}^{-1}$ (Fig. 2b), which is much higher than the global average of about $913 \mathrm{~kg} \mathrm{ha}^{-1}$ (FAOSTAT 2016) even compared to the world's leading chickpea-producing countries including India (Korbu et al. 2016). This indicates that the increased grain production resulted from an increase in the productivity of the crop per unit area (Fig. 2b). Moreover, Ethiopia has got diverse agro-ecologies that render it suitable as one of the highly productive geographies for chickpea cultivation in the world (Fikre et al. 2018).

Chickpea is cultivated almost exclusively ( 95\%) under rainfed conditions, where water stress is considered a major abiotic factor limiting growth and symbiotic $\mathrm{N}_{2}$ fixation (Wolde-meskel et al. 2018; Abdulkadir et al. 2017). Beyond its contribution as $\mathrm{N}$-fixer, chickpea can also have the ability to modify the soil climate and increase the availability of major nutrients such as $\mathrm{P}$ and $\mathrm{K}$, particularly in acidic soils where P fixation is apparent (Robson et al. 2006; Abdulkadir et al. 2017). Yet, the current national productivity level is far below the attainable yield demonstrated under optimum management practices (Fikre et al. 2018). The observed yield gap is attributable to many constraints. Chickpea is often cultivated on marginal lands, and there is also a growing perception among producers that the crop does not need additional nutrients. Consequently, farmers grow their chickpea without commercial fertilizers under suboptimal management practices. The productivity of many high-yielding elite cultivars is thus stagnating in many parts of the country, and the vast majority of smallholder farmers are harvesting far below the attainable yield.

So far, numerous research efforts have been made and several location-specific studies were conducted to identify the agronomic requirements of chickpea cultivation. However, much of the findings and information generated have been given less recognition by the users. Furthermore, the findings and research reports have not been adequately evaluated and not systematically reviewed in usable manner.

The paper, therefore, aims at reviewing the major research findings on improved chickpea agronomic practices and information generated over the past five decades, making indepth analysis of their merits, systematically compiling the scattered information for easy access and wider usage, and identifying the major production gaps. We are particularly interested in unraveling the fact that improved crop management practices are still useful strategy to enhance the stagnated yields of disadvantaged crops. We also try to prioritize researchable issues for future intervention to exploit the untapped genetic potential of the Ethiopian chickpea. Finally, we wish to highlight the role of yield-enhancing inputs in realizing the potential yield at a smallholder farm level towards strengthening the sustainability of the Ethiopian chickpea subsector.

\section{Socio-economic significance of chickpea}

There are some 12 major grain legumes produced in Ethiopia, among which chickpea is the principal crop having significant socio-economic values (Fig. 3). Chickpea is the second major export commodity next to white pea beans generating nearly 


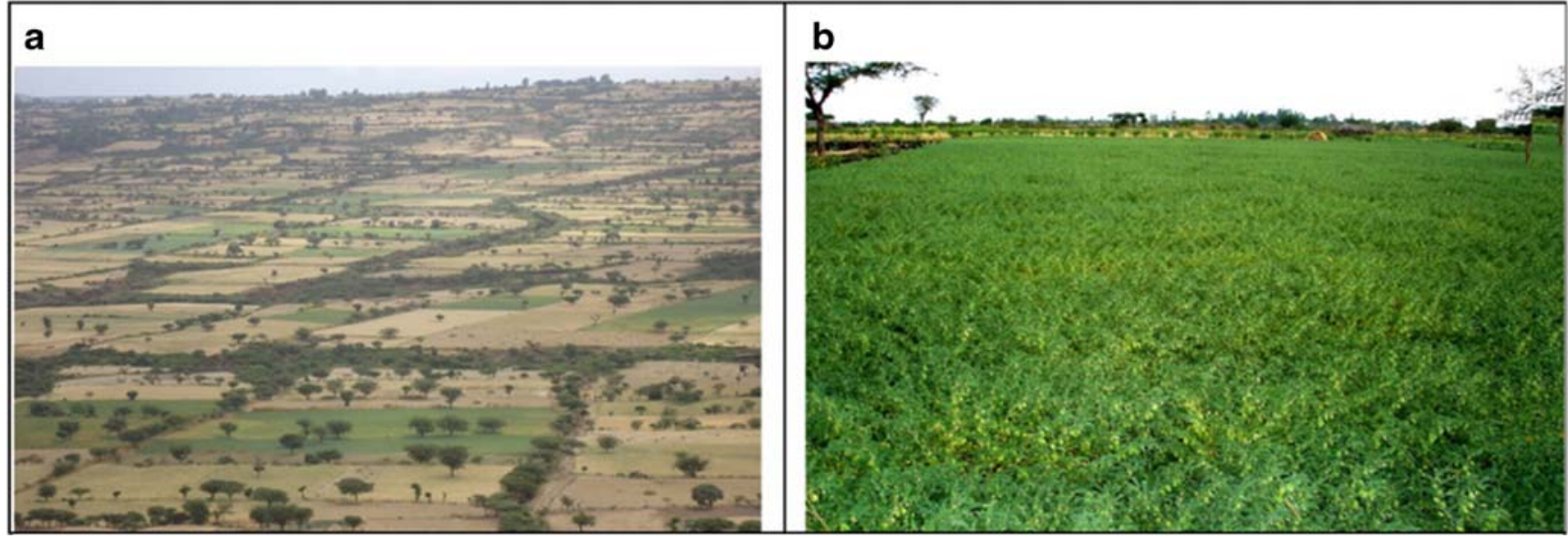

Fig. 1 Vertisol-based chickpea production in Ethiopia. a Traditional farming landscape showing chickpea as the main component of the cropping system. b Field performance of a typical high-yielding chickpea variety

Fig. 2 Trends in chickpea production and productivity in Ethiopia. a Area under chickpea cultivation and total grain production from 1992 through 2018. b Comparison of grain yields of the major food legumes grown in Ethiopia. (Source: CSA 1992-2018)

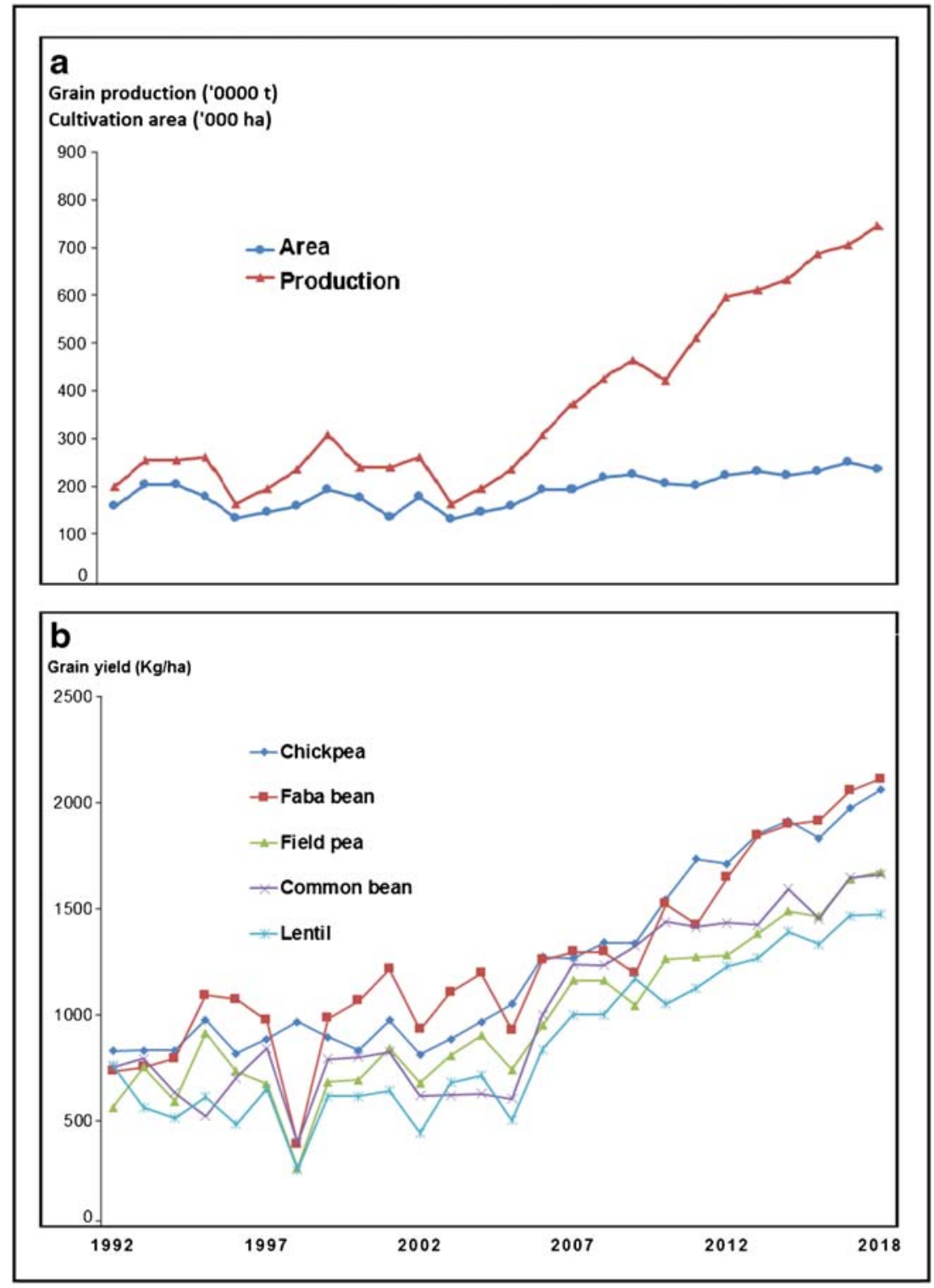


Fig. 3 The current chickpea export trend in Ethiopia - total export volume (tons) and export FOB value ('000 USD) between 2010 and 2017. (Sources: data from Ethiopian Revenue and Customs Authority (ERCA); Ferede et al. 2018; Fikre 2016)

\section{Export Volume (tons) \\ Export FOB Value ('000 USD)}

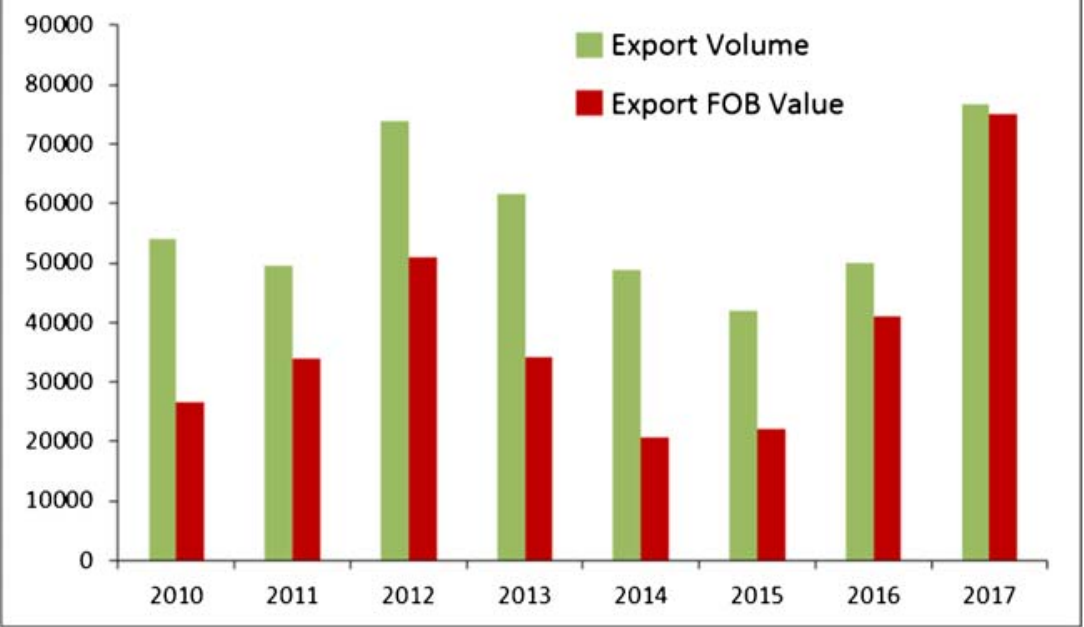

$25 \%$ of the total legumes export earnings (Ferede et al. 2018; Verkaart et al. 2017). Ferede et al. (2018) indicated that of the total annual grain trade volume of the country, the local market takes the largest share $(\sim 85 \%)$ while the export market absorbs only $15 \%$. Ethiopia has exported a total of 456,290 tons of chickpea grain during the period 2010-2017 earning a total income of 304.6 million USD (Fig. 3). The kabuli type accounted for more than $56 \%$ of the total export volume while the remaining was for the desi type (Ferede et al. 2018). Despite the fact that the current Ethiopian chickpea grain export trend shows yearly fluctuation (Fig. 3), the global market is becoming a critical destiny for the commodity proved to be competent trending an increasing market value.

Ethiopia is among the top ten chickpea-producing countries in the world and the leading producer in Africa (Fikre 2016). For longer period in the past, the crop was cultivated on subsistence basis mainly for rotational purpose between cereals and as farm household food crop (Fikre 2016). Recently, there is historical shift from its precursor status to one of toprated principal profit-making commodities. Its cultivation has assumed commercial importance over the past two decades because of the growing demand by the agro-processing industries and export market (Fikre et al. 2018).

Being a leguminous crop, chickpea exhibits an important characteristic of fixing atmospheric $\mathrm{N}_{2}$ through symbiotic association with compatible soil bacteria, replenishing the soil with additional nutrients (Amede et al. 2002; Peña and Pueyo 2012). Studies revealed that chickpea can fix up to $140 \mathrm{~kg} \mathrm{~N}_{2} \mathrm{ha}^{-1}$ and meets its $80 \% \mathrm{~N}$ requirement under the Ethiopian growing condition (Keneni et al. 2012; Fikre 2016) and thereby reduces $60-100 \% \mathrm{~N}$ requirements $(\sim$ $40 \mathrm{~kg} \mathrm{~N} \mathrm{ha}{ }^{-1}$ ) of the next cereal crop (Abdulkadir et al. 2017). This of high economic benefit fully saved a third of the entire farmland annually covered by chickpea.
Furthermore, grain legumes in general have other nonnitrogen benefits such as breaking of disease cycles, and soil structure improvement (Peoples and Craswell 1992). In Ethiopia, chickpea is predominantly grown between the two major cereals, tef and wheat, and notably reduces the risk of disease overwintering. Further, Tamene et al. (2017) reported that chickpea plays a role in modifying the soil climate and increasing the availability of major nutrients (e.g. K and P), particularly in acidic soils where $\mathrm{P}$ fixation is a problem (Schlecht et al. 2006). This unique mechanistic property of chickpea to acquire available $\mathrm{P}$ from the soil is of high agricultural importance. In dietary terms, chickpea complements cereal crops as vital source of protein and minerals for rural resource-poor farmers. Agronomically, it is an important part of crop rotations along with major cereal crops, especially in the Vertisols where other food legumes poorly adapted (Korbu et al. 2016). Grain husks after threshing the pods, dry haulms, stems, and leaves are also used as protein feed in smallholder crop-livestock system, particularly in the central highland farming systems where small-scale animal fatting farms have flourished. More importantly, domestic demand for its grain has been substantially increasing recently, and the crop commanded higher prices in local markets providing favorable returns on investment to the smallholder farmers (Ferede et al. 2018).

\section{Chickpea production bottlenecks in Ethiopia}

In Ethiopia, chickpea is generally a low-input crop grown mainly with minimum tillage. The crop is also highly sensitive to waterlogging and as a result grown largely on residual moisture following cessation of the main rainy season 
(Bejiga et al. 1997; Mamo et al. 1994). Crop damage caused by disease pathogens are among the major yield-limiting factors under rainfed Vertisol cropping systems. Ascochyta blight (AB) caused by Ascochyta rabiei and Fusarium wilt (FW) caused by Fusarium oxysporum are diseases of major economic importance (Yimer et al. 2018). Crop damage caused by $\mathrm{AB}$ is more severe when chickpea is planted early during rainy months, particularly when rainfall is accompanied by increasing humidity. Similarly, early sown chickpea is commonly subjected to the lethal effect of waterlogging, which also exposes the crop to high risk of wilt/root rot disease complex (Agegnehu and Sinebo 2012; Yimer et al. 2018). Currently, the damage caused by these two fungal pathogens is increasingly high, which in extreme cases can cause up to $100 \%$ crop losses (Yimer et al. 2018; Tebkew and Ojiewo 2016).

Conversely, late planted chickpea, as commonly practiced by the majority of Ethiopian farmers, is often facing severe moisture stress during the economic growth stage causing remarkable yield reduction (Anbessa and Bejiga 2002; Vadez et al. 2012). Terminal drought accounts for up to $50 \%$ yield losses in chickpea across the globe (Pang et al. 2017). Hence, chickpea productivity on Ethiopian Vertisols is constrained by poor drainage when sown early and by terminal drought when sown late. It is therefore important to understand these contrasting scenarios, where time of sowing would be crucial, and research needs to assist in fine-tuning the balancing strategy where farmers can maximize their benefits by avoiding both extremes.

In general, the national average yield of chickpea remains low compared with the potential mainly for two key reasons: first, the crop is often cultivated on agriculturally marginal soils using suboptimal practices (Tadele 1994; Abdulkadir et al. 2017). Second, it is grown without external inputswith a common notion among farmers that it does not need any fertilizer application (Wolde-meskel et al. 2018). Chickpea is commonly grown after major cereals, either tef or wheat, which relatively are heavily fertilized. However, chickpea yield obtained from residual fertilizers per se may not be economical to farmers because of two main reasons. Firstly, the proceeding cereals are heavy feeders leaving negligible amount in the soil. Secondly, the land allotted to chickpea is often fallowed during the main rainy months exposing the soil to erosive rains that can increase depletion of left over fertilizers by runoff or through leaching (Agegnehu and Sinebo 2012). Moreover, Ethiopian farmers often allocate much of their time and household labors for cereals and chickpea is usually receiving marginal resources. It seems that such perception still exists, and there is reluctance on the side of farmers towards the role of fertilizers in increasing crop yield.

To remediate the current situation, two issues are emphasized, which are crucial if crop productivity is to be increased with efficient resource use. First, the key challenge is how to assist farmers to change the traditional practices using on-farm demonstration of improved crop management packages. Second, evidences from agronomic studies indicated that farmers can substantially increase yield using the existing cultivars with novel soil-crop management systems (Agegnehu and Sinebo 2012; Erkossa et al. 2006).

\section{Overview of Vertisol cropping systems}

Ethiopia represents highly rugged areas in Africa, which constituted mountains, hills, plateau, plains, valleys, and gorges. The varied topographic features represent diversified elevations and slopes. The physical conditions in elevation and topography have resulted in the great diversity of climate, soil, and vegetation - all three major soil-forming factors. The diversity in climate, soil, and vegetation has encouraged the development of 18 major types of soil associations classified with the FAO/Unesco system or with the US Soil Taxonomy system (LUPRD 1984). Of the 18 soil associations existing in Ethiopia, only few are important from the agricultural development point of view. These are nitosols, $12.2 \%$ of the total land area and $23 \%$ of arable land area; cambisols, $11.6 \%$ of the total land area and $19 \%$ of arable land area; Vertisols, $9.83 \%$ of the total landmass and $18 \%$ of arable land area; and fluvisols, $8.3 \%$ of the total landmass (Fig. 4).

Vertisols or commonly known as black cotton/clay soils have an important place in Ethiopian agriculture since they are widely distributed and have diverse chemical properties (Mamo et al. 2002). The present study using contemporary tools of applied geo-spatial data infrastructures such as soil type map and LUPRD (1984) land use land cover shape files and GIS overlay analyses has shown that the total Vertisol coverage is found to be about $11 \mathrm{M}$ ha, which is $18 \%$ of the total arable land area of the country (Fig. 5). The study also revealed that the total cultivable land under Vertisol is about 4.2 $\mathrm{M}$ ha. It is important to underscore that this report makes the first of its kind and has significant agricultural policy implications in the country.

Most arable lands in the Ethiopian highlands are characterized by low crop productivity and poor soil health due to longterm nutrient mining and soil carbon decline (Wakeel and Astatke 1996; Hailu et al. 2015). The major areas of the Vertisols thus experience plant nutrient limitation as a major yield gap component (Erkossa and Teklewold 2009), especially in densely populated areas where soil fertility regeneration through fallow periods is no longer feasible (Hailu et al. 2015). About $70 \%$ ( $~ 8$ million ha) of the Vertisols is found in the highlands where chickpea is the principal rotational pulse crop (Jutzi and Abebe 1987).

According to the recent study made by Nigussie (2018), chickpea is the second crop having the largest suitability area for cultivation among food legumes next to faba bean. About 


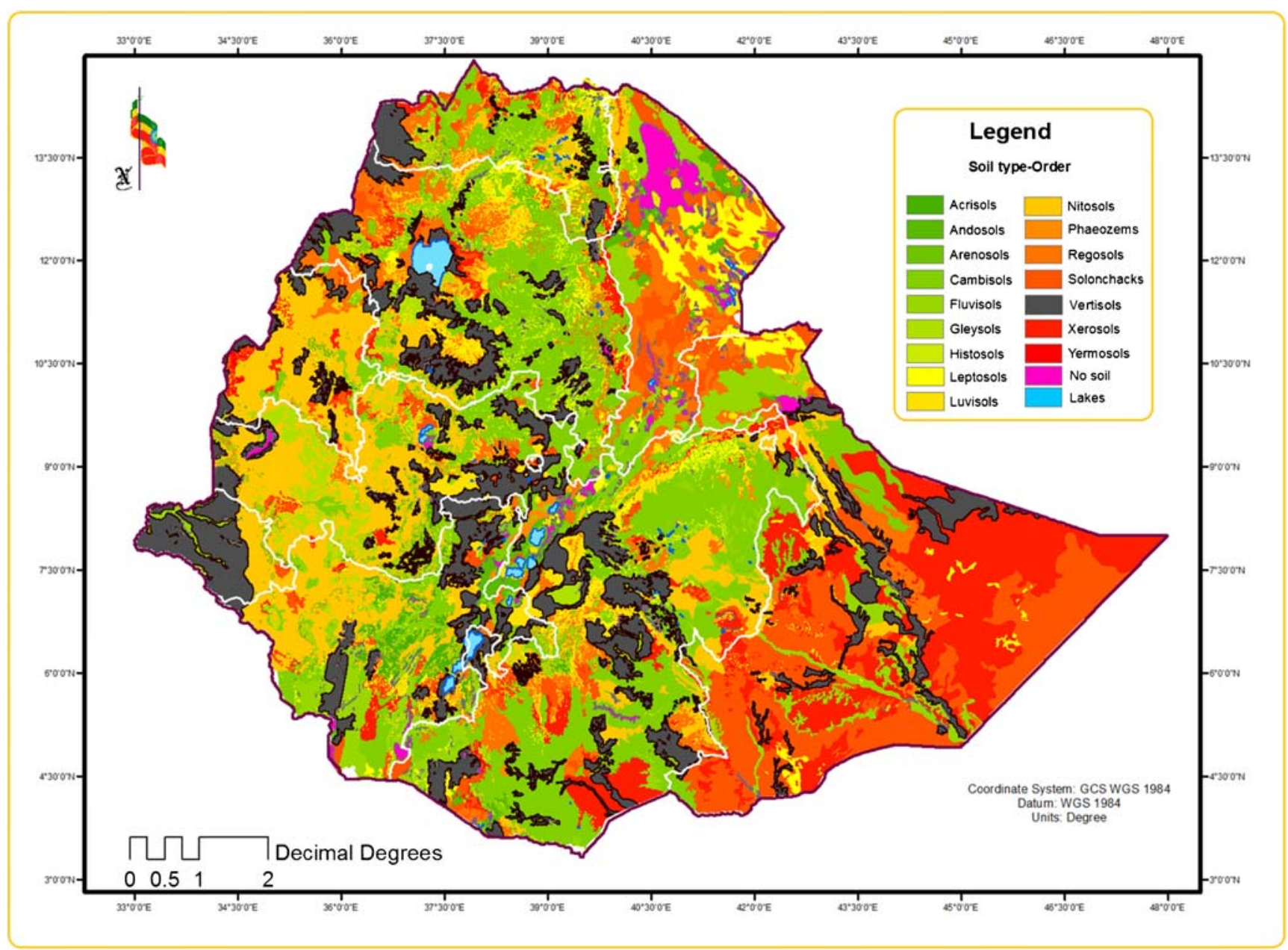

Fig. 4 Soil order map of Ethiopia with 9.83\% Vertisol (Source: LUPRD/(MoA)/UNDP/FAO 1984)

$2 \mathrm{M}$ ha is regarded as highly suitable class for chickpea production. In fact, this suitability study accounts only the biophysical aspects and does not take into account issues such as socio-economic, crop preferences, etc., which can be regarded as the primary limitation of the study in showing complete suitability scenario.

On the other hand, the annual area under chickpea remains less than 250,000 ha compared with the enormous potential. One reason could be issues related to the policy environment. The current agricultural policy of the country is overwhelmingly favoring the five cereals (wheat, maize, tef, sorghum and barely), which are regarded as sovereign crops, and legumes have been receiving limited policy recognition and hence are less competent. Secondly, Ethiopia is dominated by traditional agriculture where farmers use multiple cropping systems as risk aversion strategy.

Despite its high agricultural importance, Vertisol is generally considered as problematic soils because of its poor workability (Erkossa et al. 2006; Wubetu 2017) and is often prone to early rains waterlogging (Kanwar et al. 1982). Farmers, therefore, are forced to fallow their chickpea land during the main rainy months (June to August). In Ethiopia, chickpea is traditionally planted post rainy season on the fallowed Vertisols (Agegnehu and Sinebo 2012). This practice predisposes the crop to water-limited conditions particularly during the critical stages of grain filling leading to a considerable yield reduction. Therefore, for crops inevitability facing a number of challenges during the main production seasons like chickpea, higher productivity can be sustained through appropriate crop management practices that help to maximize proper utilization of soil-stored moisture. Among these practices, optimum planting time, surface drainage methods, and most importantly cropping system intensification are of particular importance but often given less attention.

\section{Crop diversification with chickpea: a necessity for sustainable Vertisol farming system}

The Ethiopian highlands are one of the densely populated areas in SSA ( 200 persons $\mathrm{km}^{-1}$ ) (Headey et al. 2014; 


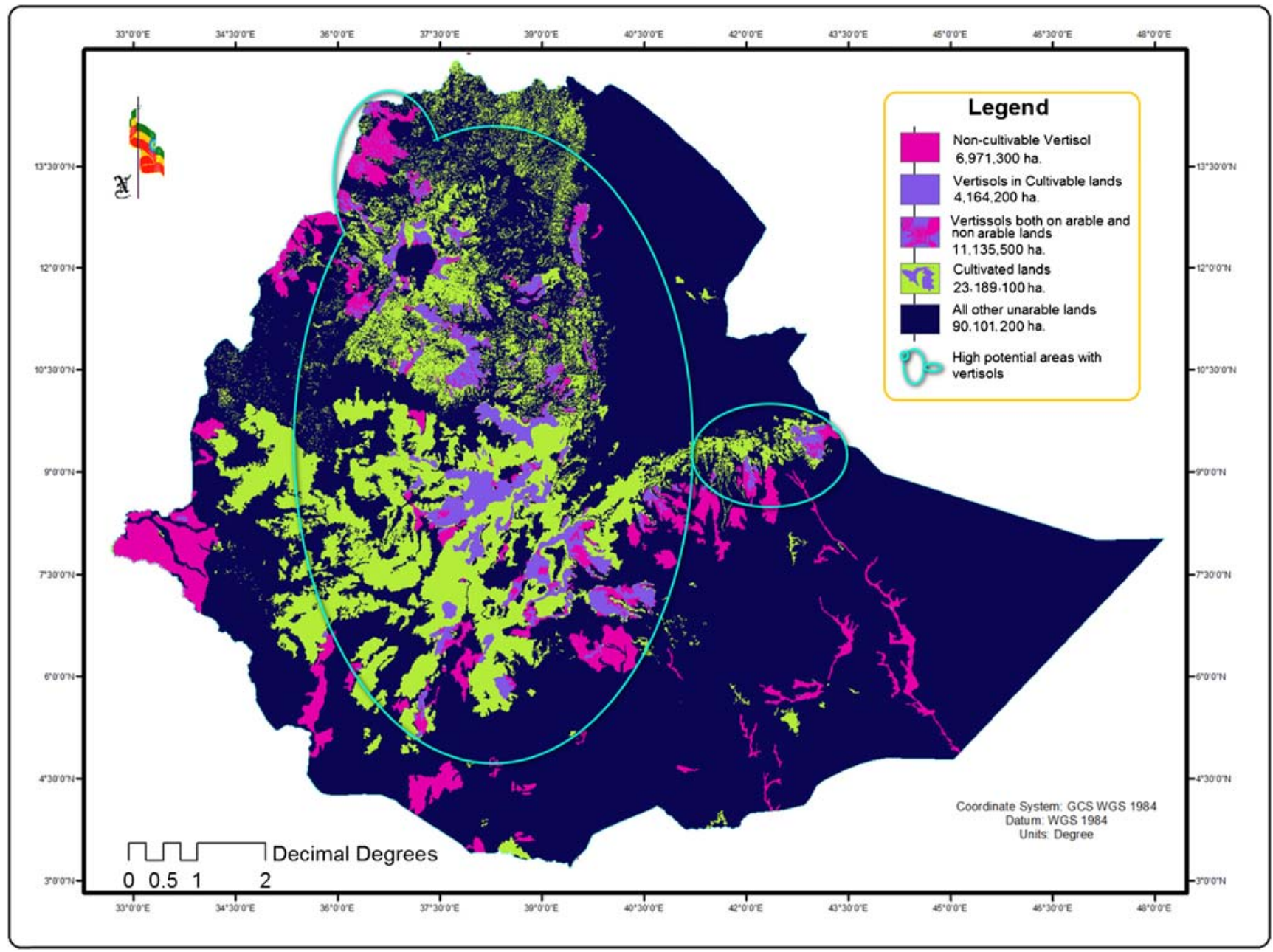

Fig. 5 Preponderance map of Vertisols with high agricultural potentials - using GIS overlay analysis on land use (cultivable vs non-cultivable) and soil type spatial data layers

ILRI 2018). Intensification of crop production is thus a must in order to feed the rapidly growing population in the region. Particularly, the integration of grain legumes in the cerealdominated Vertisol farming systems is critical for sustainability of crop production as they are vital for fertility improvement (ILRI 2018; Kanwar et al. 1982). The role of chickpea in the Ethiopian Vertisol cropping system is multifaceted. Farmers are using it mainly for its soil fertility repair, locally termed as "ikir" for subsequent staple cereals (tef or wheat). Chickpea in general plays an exceptional role in the Vertisolbased cereal-legume cropping systems where there is critically limited option of the legume component (Korbu et al. 2016), and hence vital for the sustainability of the system.

Furthermore, chickpea is the principal legume fitting into various Vertisol intensification systems (e.g., sequential cropping, intercrops, relay crops, and double cropping) in the cereal-legume production systems (Minta et al. 2014). Results obtained from wheat-chickpea double cropping field experiment conducted in the northern highlands of the Ethiopian Vertisol cropping system proved this fact (Jemberu et al.
2018). In this experiment, three popular bread wheat cultivars and two elite chickpea cultivars were used (Fig. 6). Interestingly, both chickpea cultivars gave the highest grain yield when double cropped with the superior wheat verity Dinknesh (Fig. 6), implying that both cultivars have high compatibility of fitting to the Vertisol double cropping system. Based on this finding, Dinknesh-Natoli double cropping has been verified as best cultivar combination fitting to the cereallegume double cropping systems with higher economic return. Further, this finding has demonstrated that smallholder farmers can get a remarkable economic benefit from this practice and opens up opportunities to be applied in wider areas of the Vertisol farming systems having similar agro-climatic conditions. Moreover, barely-chickpea double cropping has also been a recent trend practiced by farmers in the northern parts of the country such as in eastern Gojam zones.

Despite the numerous advantages of double cropping, finding the right compatibility of cultivars and their spatial and temporal combination is found to be critical. Several on-farm demonstrations of chickpea-based double cropping attempts 


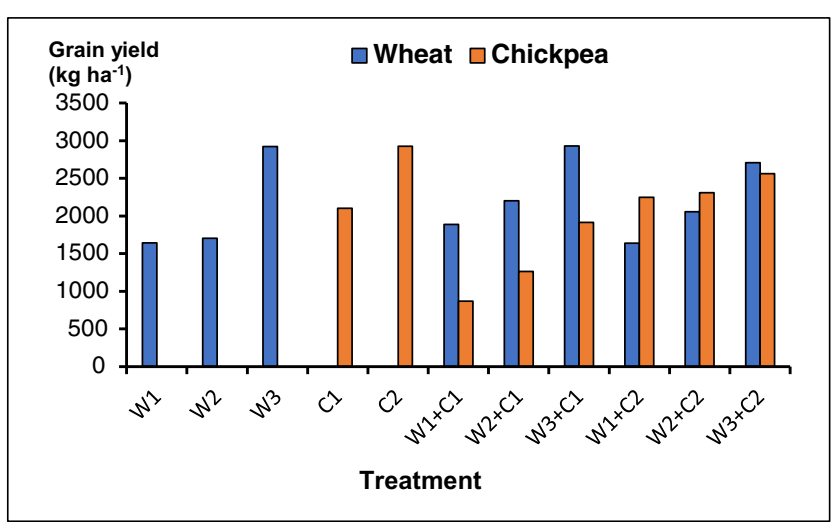

Fig. 6 Wheat-chickpea double cropping trail involving popular bread wheat and chickpea cultivars studied under on-farm and research sites in northern Vertisol crop production systems in Ethiopia during 2015 main season. $\mathrm{W} 1=$ Sole crop culture of wheat cultivar 1 (Tay), W2 = Sole crop culture of the second wheat cultivar (Senkegna), W3 = Sole crop culture of the third wheat cultivar (Dinkinesh), C1 = Sole crop culture of chickpea cultivar 1 (Habru), $\mathrm{C} 2=$ Sole crop culture of the second chickpea cultivar (Natoli), and $\mathrm{W}+\mathrm{C}=$ Wheat-chickpea double culture involving combination of each cultivar of the respective treatment (adapted from Jemberu et al. 2018)

often failed due mainly to inappropriate cultivar selection. The lack of short-duration cultivars fitting into the short growing period is the key factor limiting the practice of double cropping. Early sowing just at the onset of the main rainy season of the first cereal component is equally essential. Particularly, in some mid-altitude areas, early planting of the first crop jointly with early maturing second crop cultivar could be the best combination to practice double cropping using chickpea.

The highland Vertisol is also predominantly known by crop-livestock mixed farming system. These areas are known by chronic feed shortage because of limited (inexistent in some areas) natural pasture and high competition for crop residues as source of household fuel and energy (Amede et al. 2011). One feasible solution to this problem, which was technically deemed possible, is the introduction of fodder legumes in the traditional cereal-legume sequential cropping commonly practiced by the majority of farmers. Chickpea is commonly planted at the end of the rainy season, and hence, the land is fallowed for about 3-4 months during the rainy months. It has been observed that this practice can offer a novel opportunity of practicing double cropping. The traditional fallow system can be modified to accommodate shortduration annual fodder crops followed by early maturing and drought-tolerant chickpea cultivars (Fig. 7). The fodder species identified for this purpose includes native clovers (Trifolium species) and annual medics (Medicago species), which are adaptable to waterlogging and have faster growth rates (DZARC 2011; Kahurananga and Tsehay 1984). Moreover, the phenology and growth form of these crops make them well-suited for conserved fodder production in which they can be raised either as pure stand or in mixture with annual fodder grass species such as oats for either improved hay making or cut-carry feeding system.

Field experiment involving various sequential cropping patterns using early maturing chickpea cultivar as second crop was conducted at two Vertisol testing sites: chickpea $(\mathrm{Cp})$ planted on fully fallowed $(\mathrm{FF})$ field $(\mathrm{FF}+\mathrm{Cp})$, Vicia dasycarpa (VD) followed by chickpea (VD + Cp), Trifolium species (TS) followed by chickpea (TS $+\mathrm{Cp}$ ), and chickpea planted on partially fallowed (PF) field (PF $+\mathrm{Cp}$ ) (Fig. 7). The study revealed that the least chickpea grain yield was obtained from $\mathrm{FF}+\mathrm{Cp}$ combination at both sites over three cycles (Fig. 7). The VD + Cp combination gave $311 \mathrm{~kg} \mathrm{ha}^{-1}$ (24\%) yield advantage over the fallowed field at Akaki site while the TS + Cp combination gave $289 \mathrm{~kg} / \mathrm{ha}(28 \%)$ yield advantage at Debre Zeit site compared with the fallowed field (adapted and modified from DZARC 2011). Interestingly, the chickpea cultivar in this modified double cropping system gave comparable yield to the traditional sole cultivation, which is often practiced by farmers around the experimental sites. Apparently, compared to the traditional sequential practice, farmers can get threefold advantages from this novel practice: (1) it gives opportunity to produce high-quality fodder crops without affecting the performance of the main season food crop and (2) significantly improving yield of subsequent cereal crop that is planted on the fodder-chickpea precursor land due to enhanced N-fixation by both legume crops. (3) Farmers using this modified sequential cropping system can save about $50 \%$ of $\mathrm{N}$ fertilizer needed for the cereal cultivation in the subsequent season and enables them to increase resource use efficiency. Most importantly, the integration of fodder legumes in between cereal-food legume sequential cropping gives protection to the soil against erosive rains from fallow land.

\section{Improved chickpea cultivars and their adaptation to Vertisol cropping systems}

Since the beginning of formal research on chickpea in Ethiopia in the early 1970s, about 27 chickpea varieties: 13 desi (microcarpa) and 14 kabuli (macrocarpa) types have been developed by the research programs and released to users (Korbu et al. 2016). Each variety has its own peculiar traits with defined attributes and uses mainly for high yield, early maturing, wilt root rot resistant, and drought tolerant from both types. Most of the improved cultivars were developed for rainfed production systems, and recent reports indicated that they have demonstrated high yield potential under optimum management conditions (Fikre et al. 2018). In due courses, continuous genetic gains have been attained by the breeding programs whereby yield has been improved twice and seed size has been increased by a minimum of threefold (Bekele et al. 2016). There has also been a wide-scale 


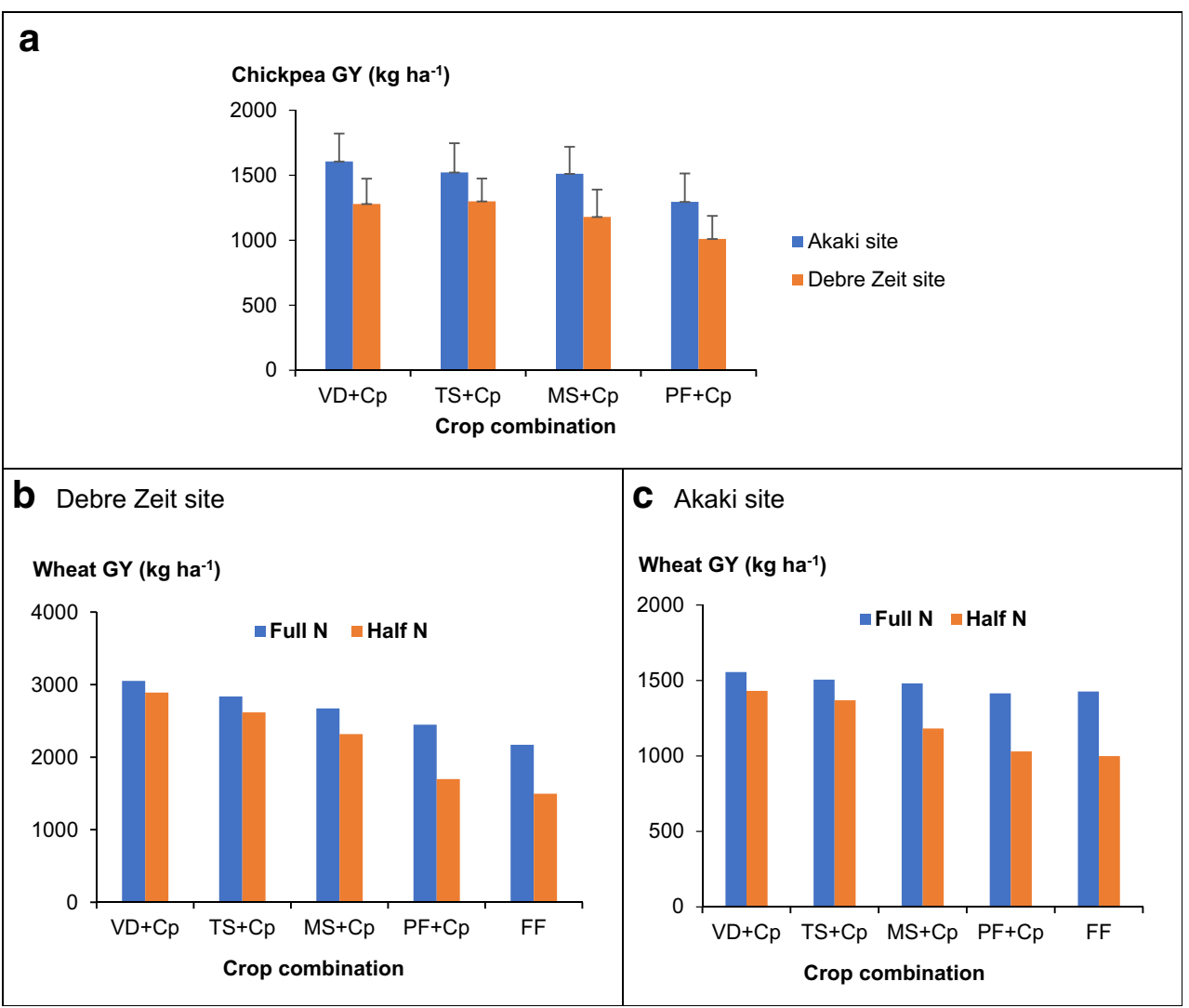

Fig. 7 A modified sequential cropping system study conducted in the central highland Vertisol-based production system. The experiment involves: fodder legumes $>$ chickpea $>$ durum wheat succession studied at two Vertisol testing sites, Akaki and Debre Zeit in Ethiopia. All fodder legumes used as first crop followed by chickpea as second crop. The cereal component is planted in the next crop cycle. a Mean grain yield (GY) of the second crop (chickpea) in the sequential crop combination at both sites. Mean GY of the cereal component (durum wheat) planted in

the third crop cycle on fodder-chickpea precursor plots in the next season using full $\left(64 \mathrm{~kg} \mathrm{ha}^{-1}\right)$ and half $\left(32 \mathrm{~kg} \mathrm{ha}^{-1}\right)$ the recommended rate of $\mathrm{N}$ application at Debre Zeit (b) and Akaki (c) sites. TS (Trifolium species), VD (Vicia dasycarpa), MS (Medicago scetellata), PF + Cp (partially fallowed field during the rainy season without fodder precursor-which is equivalent to farmers practice), $\mathrm{FF}$ (fully fallowed), which means the field was fallowed for the entire season and planted with durum in the next season. (Adapted from DZARC 2011)

adoption of improved chickpea technologies in the farming community. As a result, the national average productivity of chickpea is increased by more than $200 \%$ (threefold) which is on average over $7 \%$ increase per annum over the last two decades (Fikre 2016). More recently, Fikre et al. (2018) reported that chickpea attained the highest yield gains (over $60 \mathrm{~kg} \mathrm{ha}^{-1}$ year $^{-1}$ ) compared to the major grain legumes grown in the country. Hence, it is amenable to suggest that the rate of increasing yield has been achieved partly by the genetic gains realized.

However, unlike other major food legumes such as faba bean, genetic variation for waterlogging could not be achieved in both kabuli and desi types. This is partly because the national research program thus far has given less attention to breeding for waterlogging tolerance. Moreover, the breeding program has been primarily focusing on developing highyielding cultivars, and crop management aspects, particularly agronomic practices, have been almost overlooked. Although the high-yielding cultivars clearly demonstrated that they can bring significant yield gains, their genetic potentials, however, are still hampered by the traditional crop management practices followed by farmers and the problematic Vertisol growing condition. Hence, the cultivars need to be produced under either full drainage condition or using late plating (i.e., escape strategy) to avoid waterlogging problem. These are among the key factors limiting the genetic potential of the crop under Vertisol production system, which may need priority in the future breeding program.

Enhancing yield potentials of the major crop varieties is the key target of the current Ethiopian agricultural research and development programs. The present average farm yield of chickpea is about $55 \%$ of the yield potential ceiling of the crop (CSA 2017), suggesting that farmers can still have rooms to substantially increase yield. Several on-farm studies revealed that the national yield of chickpea can at least be doubled through the use of improved crop management practices as currently demonstrated by many adoptive farmers.

Although the current productivity level of chickpea is double the world average yield, it remains far below the attainable yield of about $3.5 \mathrm{t} \mathrm{ha}^{-1}$ observed on well-managed 
demonstration trials, and compared with the potential yield, which is verified to hit up to $6 \mathrm{t} \mathrm{ha}^{-1}$ (Fikre 2016). Likewise, there is also immense potential for expansion of area under chickpea cultivation to at least 2-3 $\mathrm{M}$ ha (Fig. 8), assuming that $65 \%$ of the total annual area covered by tef and $75 \%$ of wheat area would likely be occupied by chickpea as second rotation crop. More recently, Nigussie (2018) also reported that chickpea has the largest proportion of suitable land $(\sim$ $23.5 \mathrm{M} \mathrm{ha}$ ) among the highland food legumes in the country. Thus, the potential of chickpea area expansion is estimated to be $7.8 \mathrm{M}$ ha (Jutzi and Abebe 1987)_an area representing moderate to highly suitable land that covers some proportion of the total Vertisol area found in mid to highland areas.

\section{Advances and gaps in chickpea agronomy research in Ethiopia}

Crop management studies on chickpea were initiated in the early 1970s (Eshete 1994) following the launching of formal research on chickpea and many other crops at Debre Zeit Agricultural Research Center (DZARC). Since then, remarkable research efforts have been with regard to the development of improved chickpea production technologies. However, there is high yield gap including in the major chickpeagrowing areas of the Ethiopian highlands (Tamene et al. 2017; ILRI 2018). The major factors contributing for increased yield gaps are the expansion of biotic and abiotic constraints, weak extension, and seed systems. Above all, the suboptimal cropping system and traditional crop management practices are contributing to the greatest extent (Erkossa and Teklewold 2009; Tamene et al. 2017). On-farm demonstration of improved crop technology packages and popularization activities is often biased towards crop varieties and management aspects often overlooked (Snapp et al. 2018; ILRI 2018). Thus, studies on production agronomy are of great significance, and here, we highlighted research progress with respect to crop management of chickpea, identifying major gaps with great emphasis on important agronomic requirements under Vertisol cropping systems.

\subsection{Planting time}

Planting date is known to have a pronounced effect on growth and yield of many crops. Several studies conducted in various chickpea-growing areas in Ethiopia confirmed that time of sowing is one of the most important factors affecting yield of chickpea (Bejiga and Tullu 1982; Agegnehu and Sinebo 2012). In Ethiopia, chickpea is traditionally planted during post rainy season (September to October) on residual moisture commonly in the month of September (Bejiga and Tullu 1982). Planting can extend up to mid-October in some high rainfall Vertisol areas. Rains of the main cropping season often start in June, and the majority of the highland Vertisol areas receive their maximum precipitation in July and August. There is, however, a sharp decline in its amount and distribution from mid-August onwards (Fig. 9a). The average rainfall amount in the month of September is below $50 \mathrm{~mm}$, and thus, growth and development of late season crops such as chickpea is increasingly hindered by moisture stress during the late reproductive phases.

Field-based planting date studies carried out at Debre Zeit research station for several years using popular chickpea genotypes revealed that 1 st of September was found the best sowing date having 35\% yield advantage over later sowing dates (Bezuneh 1975). Later on, on-farm studies in major growing areas indicated that mid-August to early September is the ideal period for chickpea planting under rainfed condition (Bejiga and Tullu 1982). More recently, a simulationbased sowing time study conducted in two sites of the northeastern region using CROPGRO model (Hoogenboom et al. 2010) indicated that mid-August sowing had significant yield advantage over the traditional late (September) sowing (Mohammed et al. 2017).

Fig. 8 Current status and future potentials of the Ethiopian chickpea subsector (Sources: Fikre 2016; CSA 2017)

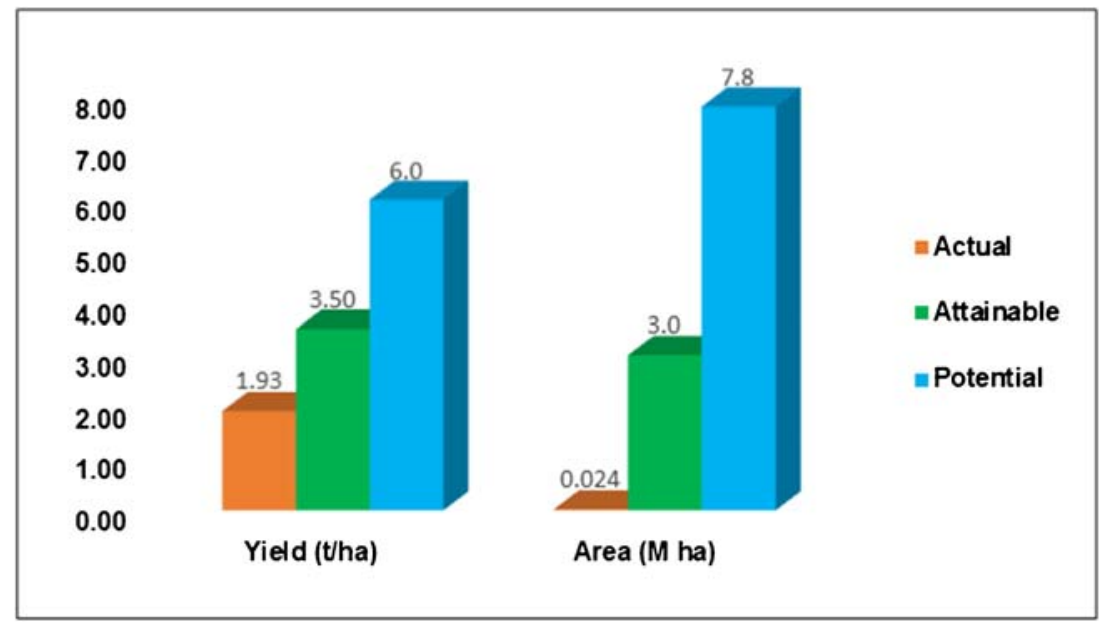


Fig. 9 a Twenty-year (19982018) average monthly rainfall pattern of the main chickpea research station at Debre Zeit, Ethiopia, during chickpeagrowing season. b Mean grain yield $\left(\mathrm{t} \mathrm{ha}^{-1}\right)$ of chickpea genotypes planted on different sowing dates (pooled into weeks) on experimental field conditions in Ethiopia. The data were extracted from results of different field trials conducted over the past several years (1971-2014) mainly on Vertisol testing sites (Debre Zeit, Akaki, Chefe Donsa, and Ginchi) representing the central highland Vertisol chickpeagrowing areas. c Probability of dry spell lengths (number of days) to occur for seven, ten and 15 consecutive days in each month of a season in the station over the last 32 years (1983-2015). (Sources: Bezuneh 1975, Bejiga and Tullu 1982; Eshete 1994; Bejiga et al. 1994; DZARC's weather station)

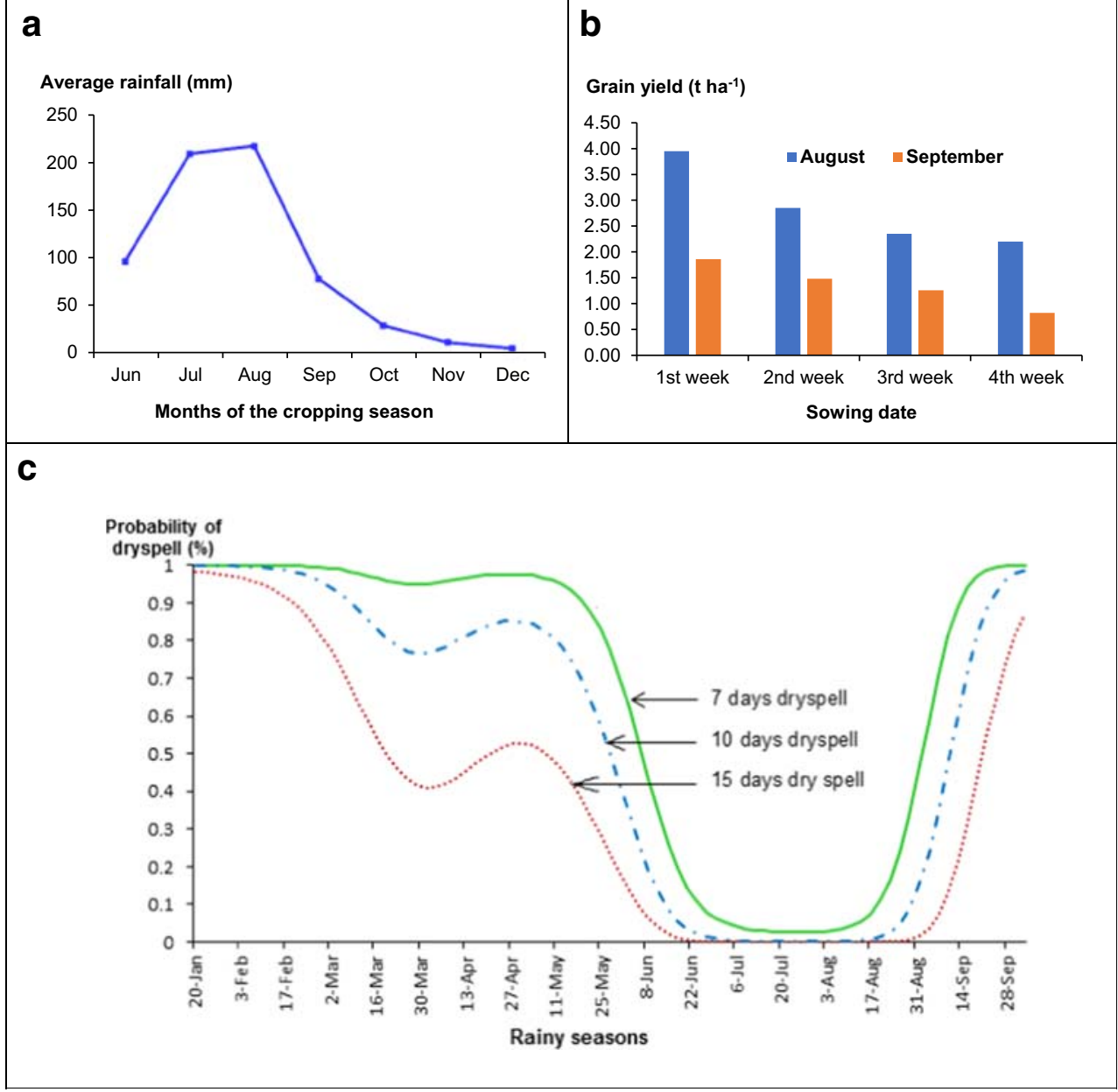

Most of these and earlier studies reported that any delay from this time window can cause up to $50 \%$ yield reduction (Fig. 9b) regardless of the type of genotype used (Eshete 1994). Bejiga and Tullu (1982) also reported up to $100 \%$ yield losses if planting is extended up until the last week of September. The probability of dry spell period to occur for more than 15 consecutive days in the month of September is more than $10 \%$ (Fig. 9c). In areas where there is inadequate precipitation, or when early cessation of rain is a case, planting should be made much earlier in the season. It is worth mentioning, however, that sowing date of chickpea greatly varied from place to place depending mainly on rainfall amount and its seasonal pattern. Hence, the traditional fixed sowing date system needs to be complemented by local climate forecastbased advisory services that account for climate variability. More importantly, verification trails may be needed to establish proper climate-based sowing dates in new intervention areas.

On the other hand, many recent reports suggested that early sowing of chickpea needs to be combined with improved drainage systems (Agegnehu and Sinebo 2012; Ayana 2014). A study made by Ayana (2014) particularly confirmed earlier reports that mid-August is the ideal time for sowing chickpea under highland Vertisol areas. Interestingly, early planting can be accounted for $44 \%$ yield gains in the Vertisol cropping system of the central highlands (Fig. 9b), underlining that effective drainage option pays. From these studies, it is evident that early-season planting of chickpea is still an advantage, given the ever-increasing climate change impacts - the gradual declining of rainfall amount and its erratic nature (Morton 2007). Shift in planting time is a feasible option, which is also believed to be the simplest, low-cost, and farmer-adoptable climate change adaptation strategy (Vanlauwe et al. 2014; Morton 2007).

Under the Ethiopian heavy Vertisol cropping system, sowing time is mainly driven by the condition of abiotic and biotic stresses. Early-season planting of chickpea is usually associated with severe waterlogging, and seedbed preparation is also hampered by the physical property of these soils (Jutzi and Abebe 1987; Agegnehu and Sinebo 2012). If at all possible, early planting exposes the crop to increased risk of yield losses from soil-borne diseases, mainly wilt/root rot complex (Yimer et al. 2018; Beniwal et al. 1992). As a result, a significant number of farmers are still adhering to the traditional late sowing, after the off-set of the rainy season, and the crop is forced to grow on residual moisture. Late sowing may help in minimizing the damage caused by foliar diseases like 
Ascochyta blight; however, there is high chance of exposing the crop to moisture stress. Early planting of chickpea on Vertisols may be possible by either developing effective surface drainage techniques, chemical control of the major diseases, or integration of the two. The third strategy would be increasing crop tolerance to waterlogging and soil-borne diseases through the development of disease-resistant chickpea lines with the help of advanced tools of breeding and genetic manipulations.

In conclusion, for Vertisol crops like chickpea, the ideal time of sowing is a perfect balance between avoiding severe waterlogging from early-season planting and the increased risk of terminal drought from late planting.

\subsection{Planting density}

Ethiopian farmers generally use relatively lower seed rates than research recommendations, which may also be regarded as one of the factors responsible for lower yields. Some dated studies reported that there were no significant differences between different seeding rates on grain yield of chickpea (Eshete 1994; Bejiga et al. 1994). Later, Agegnehu et al. (2006), on the other hand, found a significant difference among the seed rates studied and obtained highest grain yield at higher seed rate. Recently, Shiferaw et al. (2018) reported that chickpea cultivars planted at higher densities $(10 \mathrm{~cm} \times 20 \mathrm{~cm}$ between plants and rows spacing) gave the highest grain yield. Coupled with this result, Agajie (2018) reported that $10 \mathrm{~cm} \times 30 \mathrm{~cm}$ spacing resulted in the highest grain yield, which also confirmed the earlier recommendation (Eshete 1994). These and many other studies reported that chickpea plant better tolerate higher plant population culture. The possible explanation for this is that higher plant density may enhance competition for resources (light, space, and nutrients) and better stored soil moisture due to lower evapotranspiration rates.

Moreover, Eshete (1994) reported that yield of chickpea showed an increasing trend for higher plant population (e.g. 50 plants $/ \mathrm{m}^{2}$ ), which also was recently confirmed by Shiferaw et al. (2018) suggesting the use of 65-85 kg seeds per hectare. However, these recommendations could not take into account the seed size variations among the popular cultivars that greatly determine seeding rate. In order to establish optimum plant density that can maximize yield, and to ensure efficient use of resources, seeding rate of chickpea still needs to consider germination percentage of the seed, growth habit of a given cultivar, and most importantly the drainage condition and disease load of the soil.

\subsection{The dilemma of fertilizer application on chickpea}

The Ethiopian highland Vertisol crop production is characterized by a subsistence rainfed system where a large number of farmers depend on for livelihoods (Clarke et al. 2017; Abdulkadir et al. 2017). In this system, legumes are often considered as secondary to cereals and are generally promoted as crops that require no inputs. According to the recent reports of the national soil analyses results, the vast majority of agricultural soils in most parts of the highlands have low fertility (EthioSIS 2014).

Despite the growing attention given to chickpea as highvalue chain commodity, it is still considered as subsistence crop, and the majority of farmers produce without fertilizers. This may be because of the historical generalization and assumption that the crop can fulfill all of its nutrient requirements through the natural N-fixation. The beneficial effect of fertilizer application (specifically NPK, and occasionally S) on chickpea yield gains is an established fact across the world (Verma and Pandya 2003; Saeed et al. 2004).

About $60 \%$ of the Ethiopian highland Vertisols are in the range of slightly acidic with $\mathrm{pH}$ ranging 5.5-6.7 (Mamo et al. 1993), suggesting the importance of proper fertilization to sustainably increase crop yield on these soils. Most importantly, as described by Goud et al. (2014), fertilizer supply is commonly associated with improved protein content in grains, improved $\mathrm{N}$ fixation, and water use efficiency. Local agronomic studies have also suggested that fertilization enhances plant growth, grain and biomass yield, symbiosis efficiency in chickpea (Wolde-meskel et al. 2018; Amede et al. 2002).

\subsection{Response of chickpea to $\mathrm{N}$ application}

Nitrogen $(\mathrm{N})$ and phosphorus $(\mathrm{P})$ are often the limiting nutrients for crop production in tropical soils (Mamo et al. 2002). Recent studies also revealed that a significant proportion of the Ethiopian highland Vertisols where the bulk of chickpea is produced is deficient in their NP contents (Asrat et al. 2016; EthioSIS 2014). This situation is aggravated by nutrient depletion through continuous cultivation without adequate replenishment (Hailu et al. 2015).

Chickpea is regarded as one of the high N-fixers (Saxena 1980), provided that the natural process is supportive of effective symbiotic fixation. The soil must also have sufficient population of compatible rhizo-bacterium or calls for inoculant application otherwise (Beck 2010). The total $\mathrm{N}$ uptake by a chickpea plant has been estimated to vary from 60 to $143 \mathrm{~kg} \mathrm{ha}^{-1}$ (Saxena 1980; Goud et al. 2014), and one needs to verify whether the growing conditions enable the crop to fix that amount. Studies revealed that chickpea can fix $60-80 \%$ of its $\mathrm{N}$ requirements under favorable conditions (Wolde-meskel et al. 2018; Beck 2010).

Nitrogen and phosphorus are the major chemical fertilizers widely used by Ethiopian farmers in the form of urea and DAP (Tamene et al. 2017; Abdulkadir et al. 2017). However, little is known on the impact of NP applications on chickpea grain yield, and its nutrient requirement is not yet well-defined 
under Vertisols in particular. Some outdated studies reported that chickpea is non-responsive to nitrogen application as they found non-significant difference between N-fertilized cultivars and their unfertilized counterparts (Eshete and Beniwal 1987; Eshete 1994). Poor soil fertility, especially the P level of the research plot, could be one of the constraints creating nonresponsiveness as chickpea is often grown on marginal land. Consequently, these generalized reports have led to the notion that chickpea does not need any kind of nutrient application (Chala et al. 2018; Wolde-meskel et al. 2018), and even to the extent that studies focusing on chickpea fertilization have given less attention for years.

Apparently, these earlier studies had at least three technical limitations: first, soil $\mathrm{N}$ status before conducting the trials was not supported by soil test information. Second, information about the status of native rhizobia population was also unknown - whether the fixed $\mathrm{N}$ level was adequate for normal growth and development of the crop. Third, all the trials were conducted on a single testing site and critically lacking both site as well as seasonal replication (i.e., the wide-ranging growing conditions were not adequately represented). Hence, it is evident that earlier studies on the responses of chickpea to fertilizer application in general were not adequately studied. Thus, given the limited research efforts made, it is likely that these dated recommendations have remained misleading (Tamene et al. 2017).

Recently, however, there are increasing evidences demonstrating the positive benefits of fertilizer application on chickpea, refuting earlier reports (Erkossa and Teklewold 2009). A recent fertilizer study conducted at two Vertisol sites in Ethiopia indicated that the application of $50 \mathrm{~kg} \mathrm{DAP} \mathrm{ha}^{-1}$, which is half the earlier recommended rate, gave comparable grain yield with $100 \mathrm{~kg}$ rate and had $11 \%$ yield advantage over unfertilized control (Mola, unpublished data). Asrat et al. (2016) also reported that $\mathrm{N}$ application markedly improved overall agronomic performances of chickpea cultivars studied on Vertisols at Debre Zeit site. Similarly, an on-farm fertilizer trail conducted in the southern region revealed that NP fertilizer application has significantly increased the biomass and grain yield of chickpea cultivar compared with unfertilized control (Woldesenbet et al. 2013). According to this study, $11.5 \mathrm{~kg} \mathrm{~N}$ and $10-20 \mathrm{~kg} \mathrm{P}$ rates were found economically viable and hence recommended for optimum chickpea production in the region. Wolde-meskel et al. (2018) also reported that nutrient (specifically $\mathrm{N}$ ) application has significantly enhanced symbiotic efficiency in chickpea. More recently, an on-farm study made by Chala et al. 2018 revealed that the application of half the recommended rate of NP fertilizers (in the form of DAP) gave double grain yield and biomass of chickpea as compared to the unfertilized control.

Elsewhere, several investigators also reported the positive response of chickpea to a starter application of 15$25 \mathrm{~kg} \mathrm{~N} \mathrm{ha}^{-1}$ prior to or during planting, which also enhanced seedling development and plant growth (Shah et al. 2016; Snapp et al. 2018). Further, Dahiya et al. (1993) determined nutritional requirement of chickpea and reported that chickpea cultivars studied attained their highest yields using $27 \mathrm{~kg} \mathrm{~N} \mathrm{ha}^{-1}$ and $69 \mathrm{~kg} \mathrm{P} \mathrm{ha}^{-1}$. The aforementioned evidences and many other experimental examples illustrate that chickpea is responsive to the application of both inorganic (Chala et al. (2018) and organic (Debele and Deressa 2016), and it is well verified that grain yield has significantly increased with the application of $\mathrm{N}$ under Vertisol production systems (Mamo et al. 2002; Agegnehu and Sinebo 2012).

In conclusion, the common perception among farmers that chickpea does not need nutrient application has contributed to a greater extent for lower national yield in Ethiopia. Considering the increasing fertility depletion on most of the agricultural soils, the use of major yield-enhancing fertilizers is becoming indispensable to alleviate soil nutrient deficiencies and narrow down the huge yield gaps existing between the actual and attainable level towards realizing food security in the country.

\subsection{Response of chickpea to $P$ application}

Phosphorus plays an important role in enhancing N-fixation by stimulating host plant growth (Robson et al. 2006). The total $\mathrm{P}$ uptake by chickpea plant is estimated to vary between 5 and $10 \mathrm{~kg} \mathrm{ha}^{-1}$ (Saxena 1980) depending on the growing conditions. Saxena (1980) further reported positive response of chickpea genotypes to $\mathrm{P}$ application, ranging between 50 and $75 \mathrm{~kg} \mathrm{P}_{2} \mathrm{O} 5 \mathrm{ha}^{-1}$ in several growing areas in India.

In Ethiopia, Eshete and Beniwal (1987) and Eshete (1994) found non-significant yield differences between three rates of $\mathrm{P}$ (30, 60, and $\left.90 \mathrm{~kg} \mathrm{P}_{2} \mathrm{O}_{5} \mathrm{ha}^{-1}\right)$ applied to chickpea genotypes grown on Vertisol. Similarly, Mamo et al. (1993) reported that chickpea genotypes were non-responsive to $\mathrm{P}$, and consequently, its application is totally neglected in Ethiopia. Many agricultural soils have high P-fixing properties (Saxena 1980), implying that there is high chance of getting lack of crop response to $\mathrm{P}$ application. This might also be one of the reasons that many investigators failed to find positive response to $\mathrm{P}$ applied. Nonetheless, Eshete (1994) suggested a starter application of $100 \mathrm{~kg} \mathrm{DAP} \mathrm{ha}{ }^{-1}$ to chickpea although there was no strong evidence supporting this "blanket recommendation."

A number of recent studies, however, found that chickpea is significantly responsive to $\mathrm{P}$ application. Interestingly, Mamo et al. (2002) found that P uptake by chickpea increased by many folds compared with wheat crop in a multi-site trial, which also considerably manifested by enhanced dry matter yield. A field trail conducted in the northeastern highland Vertisols also revealed that $\mathrm{P}$ has significantly improved key agronomic traits (Hussen et al. 2013), and hence, $60 \mathrm{~kg} \mathrm{P} \mathrm{ha}^{-1}$ was recommended for the study areas and other chickpea production zones having similar agroecology. A more 
comprehensive on-farm field study revealed that the application of $\mathrm{P}$, either alone or along with rhizobial inoculation, increased $\mathrm{N}$ uptake of chickpea genotypes by $14-25 \mathrm{~kg} \mathrm{ha}^{-1}$ comparing with the control (Wolde-meskel et al. 2018). This study further indicated that $\mathrm{P}$ application substantially enhanced $\mathrm{N}$-fixation and increased grain yield by many folds (Woldemeskel et al. 2018). Agronomic studies on chickpea in Ethiopia have further verified that earlier recommendation of $100 \mathrm{~kg} \mathrm{ha}^{-1}$ of DAP application is far different from the realistic situation, considering the fact that fertilizers are expensive commodities in Ethiopia where small-scale farmers hardly afford.

Apart from the commonly used NPK fertilizers, sulfur (S) is also one of the essential plant nutrients often neglected in many crop production systems. Chickpea is responsive to $\mathrm{S}$ application as well (Das et al. 2016). Recently, Shewangizaw et al. (2019) reported that the application of $30 \mathrm{~kg} \mathrm{~S} h a^{-1}$ substantially increased grain yield of chickpea genotypes under rainfed conditions in the Ethiopian highlands. However, response of chickpea to $\mathrm{S}$ application is not well studied and its economic benefits are not yet determined.

Overall, we have identified that fertilizer studies carried out in the past had serious limitations, many of which reached on the conclusions that chickpea is non-responsive to any chemical fertilizers. Recently, there is an increasing evidence to suggest that the application of inorganic fertilizers significantly enhanced plant growth, grain and biomass yield, and symbiotic efficiency of chickpea. It is important to underscore, however, that any fertilizer recommendation needs to be site and context specific depending on soil-test analyses. Moreover, investment on an input must also make economic sense to farmers to adopt.

\subsection{Response of chickpea to organic fertilizers}

There is a long tradition of using organic fertilizers mainly farmyard manures (FYM) as main source of soil nutrients by most of the Ethiopian smallholder farmers (Erkossa and Teklewold 2009). Recent reports, however, are alarming that about $80 \%$ of the FYM is used as household energy sources in the major crop-livestock farming systems of the highland areas (Amede et al. 2011; Abdulkadir et al. 2017). There is also a strong competition for crop residues as animal feed and cooking fuel, and hence, little is remaining for the soil, suggesting the importance of looking for alternative energy sources in the farming community.

A recent study made by Debele and Deressa (2016) found positive response of chickpea cultivars to the application of FYM along with $\mathrm{N}$. According to this report, the highest grain yield was obtained with the application of $6 \mathrm{t}$ FYM with zero $\mathrm{N}$ level (Table 1), implying that farmers can sustain the productivity of their chickpea crop using FYM without the need for inorganic sources. This might be due to the role of FYM in promoting the release of soil $\mathrm{N}$ or enhanced BNF efficiency of
Table 1 Response of chickpea cultivar expressed as grain yield to combined application of different $\mathrm{N}$ rates and FYM under Vertisol field condition (Source: Debele and Deressa 2016)

\begin{tabular}{lllll}
\hline FYM $\left(\mathrm{t} \mathrm{ha}^{-1}\right)$ & \multicolumn{2}{l}{ Nitrogen rate $\left(\mathrm{kg} \mathrm{ha}^{-1}\right)$} & Mean \\
\cline { 2 - 4 } & 0 & 30 & 60 & \\
\hline 0 & 2379 & 2535 & 2548 & 2487 \\
30 & 2650 & 2347 & 2664 & 2554 \\
60 & 2746 & 2596 & 2448 & 2597 \\
Mean & 2592 & 2493 & 2553 & - \\
\hline
\end{tabular}

the host plant. Interestingly, there was a clear yield advantage resulted from the application of $\mathrm{N}$ along with FMY compared with unfertilized control (i.e., zero $\mathrm{N}$ rate). Hence, the study suggested that the combined application of $3 \mathrm{t}$ FYM with $30 \mathrm{~kg} \mathrm{~N} \mathrm{ha}^{-1}$ is economically feasible to optimize grain yield and biomass of chickpea.

Similarly, Chala et al. (2018) reported that chickpea cultivars gave maximum grain and biomass yields when different types of FYM were applied under on-farm field conditions. The application of 50\% vermicompost (VC) and 50\% FYM along with half $(50 \%)$ the recommended rate of NP fertilizers significantly increased grain yield by $715 \mathrm{~kg} \mathrm{ha}^{-1}(26 \%)$ and $481 \mathrm{~kg} \mathrm{ha}^{-1}(20 \%)$, respectively, over the application of each of these organic sources alone (Table 2). Interestingly, the impact of both VC and FYM was positively and substantially improved when applied with NP compared with each of these organic sources alone (Table 2), implying that inorganic fertilizers may have additional role of enhancing the release of plant-available nutrients from organic sources. The application of 50\% VC/FYM together with 50\% NP fertilizers gave about threefold grain yield and biomass yield advantage over farmers' practice (Chala et al. 2018). Such examples illustrate that the combined application of locally available organic nutrients along with NP fertilizers is more beneficial than the sole application of either of the input types. Interestingly, the findings have also confirmed that chickpea is truly responsive to both inorganic (NPS) and organic (VC and FYM) nutrients and are in support of our argument presented in this review. Likewise, several studies on the integrated use of organic and inorganic nutrients have reported similar results in other major food crops including wheat and tef (Debele and Deressa 2016; Erkossa and Teklewold 2009). These studies have clearly demonstrated the opportunity that a significant number of farmers can be benefited from the application of easily available organic matters to their chickpea crop.

\subsection{Chickpea response to Rhizobacterial inoculation}

Increasing biological nitrogen fixation (BNF) is the most feasible strategy to enhance sustainable crop productivity in the 
Table 2 Impacts of the application of different organic and inorganic fertilizers on the agro-morphological functionality of chickpea (Adapted from Chala et al. 2018)

\begin{tabular}{lllllll}
\hline Treatment & PH $(\mathrm{cm})$ & $\mathrm{GY}\left(\mathrm{kg} \mathrm{ha}^{-1}\right)$ & $\mathrm{BM}\left(\mathrm{kg} \mathrm{ha}^{-1}\right)$ & \multicolumn{2}{l}{$\%$ increase over the control } \\
\cline { 5 - 7 } & & & & PH & $\mathrm{GY}$ & $\mathrm{BM}$ \\
\hline Recommended NP & 44.2 & 1889 & 6806 & 15.7 & 49 & 46 \\
Vermicompost (VC) & 40.2 & 1997 & 6680 & 5.20 & 52 & 45 \\
Farmyard manure (FYM) & 41.3 & 1901 & 6280 & 8.10 & 49 & 41 \\
$50 \%$ VC + 50\% NP & 47.8 & 2712 & 10,030 & 25.1 & 64 & 63 \\
$50 \%$ VC + 50\% FYM & 41.5 & 1869 & 6673 & 8.60 & 48 & 45 \\
$50 \%$ FYM + 50\% NP & 42.0 & 2382 & 7665 & 9.90 & 59 & 52 \\
Control & 38.2 & 965 & 3680 & - & - & - \\
\hline
\end{tabular}

$P H$ plant height, $G Y$ grain yield, $B M$ biomass yield cereal-legume cropping systems (Murray et al. 2017; Esfahani et al. 2014). By virtue of its high $\mathrm{N}_{2}$-fixing capacity, chickpea plays exceptional role for the sustainability of the cerealdominated Vertisol farming system of the Ethiopian highlands (Keneni et al. 2012; Fikre 2016). Symbiotic N-fixation is known to be affected by several factors, among which soil properties like $\mathrm{pH}$ and nutrient content are the prominent ones (Evans 1982; Kumar et al. 1996). Reports highlighted that nutrient deficiency, particularly $\mathrm{P}$, can considerably reduce the BNF process in legumes (Robson et al. 2006; Murray et al. 2017). This is of particular importance under the present curb of technological provision and price regimes of commercial fertilizers.

Recently, Wolde-meskel et al. (2018) found that chickpea genotypes inoculated with native rhizobia strains showed higher $\mathrm{N}$ uptake and substantially increased grain yield by many folds compared with uninoculated control (Table 3). More interestingly, this study has revealed that the application of $23 \mathrm{~kg} \mathrm{P} \mathrm{ha}{ }^{-1}$ alone has comparable yield advantage with the inoculation treatment alone, which further confirms that chickpea is responsive to $\mathrm{P}$ application. In general, it is in this context that responsiveness to and profitability of fertilizer application to chickpea crop assumes considerable economic significance.

In Ethiopia, studies on bio-fertilizers were initiated as early as 1982 on common bean (Mamo and Dibabe 1994). The national research has been consolidated at Holetta Agricultural Research Center since 1984, the main focus being BNF on highland pulses. Since then, effective strains of rhizobia associated with six major pulse crops (chickpea, faba

Table 3 Overview of chickpea responses to $\mathrm{P}$ fertilization and rhizobia inoculation on yield and $\mathrm{N}$ uptake (Adapted from Wolde-meskel et al. 2018)

\begin{tabular}{llll}
\hline Input & $\begin{array}{l}\mathrm{GY} \\
\left(\mathrm{kg} \mathrm{ha}^{-1}\right)\end{array}$ & $\begin{array}{l}\text { GY increase } \\
\left(\mathrm{kg} \mathrm{ha}^{-1}\right)\end{array}$ & $\begin{array}{l}\mathrm{N} \text { uptake } \\
\left(\mathrm{kg} \mathrm{ha}^{-1}\right)\end{array}$ \\
\hline P application (P) & 1946 & 335 & 63.0 \\
Inoculation (I) & 2024 & 413 & 67.3 \\
$\mathrm{P} \times \mathrm{I}$ & 2215 & 604 & 78.0 \\
Control & 1611 & - & 53.5 \\
\hline
\end{tabular}

bean, field pea, common bean, lentils and soybean) were identified (Mamo and Dibabe 1994), and efforts have been made to develop inoculants as part of production packages (ILRI 2015). So far, only few native strains of chickpea rhizobia were identified, among which the two Mesorhizobium strains "CP-41" and "CP-029" are reported as effective commercial inoculants widely used by farmers (Wolde-meskel et al. 2018).

Despite the enormous economic and environmental benefits, the use of bio-fertilizers in general has remained weak due to limited options of effective commercial BNF inoculants adaptable to diverse growing conditions and poor supply system. Furthermore, many reports have highlighted that the potentials of the native rhizobia population existing in the country is untapped. Therefore, extensive and systematic survey collection programs covering a wide range of chickpeagrowing agro-ecologies are highly needed in order to address the current research gaps.

\subsection{Response of chickpea to drainage methods}

Despite the fact that chickpea is more adaptable to the Vertisol growing conditions, its productivity, however, is highly affected by the waterlogging problem of the soil. The crop thus has to be produced under effective drainage condition. The land allotted to chickpea is often left bare during the rainy months exposing the soil to erosive rains that can increase the rate of fertility loss via heavy runoffs (Agegnehu and Sinebo 2012). The advantages of improved drainage system combined with early sowing on Vertisol have been demonstrated in several major crops (Agegnehu and Ghizaw 2004; Abebe et al. 1994), and recently on chickpea (Agegnehu and Sinebo 2012). In agreement with this result, Belayneh (1986) also highlighted the advantage of improved drainage system called the camberbed method for heavy vertic soil, and Bejiga et al. (1994) indicated the importance of optimum sowing dates for better yield at Debre Zeit site (black cotton soil).

Agegnehu and Sinebo (2012) further emphasized the importance of the interactive effect of drainage methods and sowing date in the highland Vertisol growing zones. They 
found highly significant effect of drainage method by cultivar interaction on grain yield of chickpea, implying the genetic potentials of modern cultivars are more influenced by the drainage conditions. Similarly, a field trail conducted by Ayana (2014) reported that raised-bed methods increased biomass yield of chickpea by about $58 \%$ and grain yield by $74 \%$ as compared to the un-drained flatbed method (Fig. 10). This finding further confirmed earlier findings of Agegnehu and Sinebo (2012) who reported a similar trend in field trials. It is evident from these reports that chickpea cultivars are more sensitive to seedbed type (i.e., drainage conditions) than time of sowing under Ethiopian rainfed production systems. However, the studies indicated that there is a general trend of yield reduction for extended time of sowing beyond mid of August under vertic type of soils. In general, several reports emphasized the importance of integrating early sowing, proper surface drainage methods, and optimal nutrient use for enhanced Vertisol productivity in Ethiopia.

Productivity of Vertisol-grown legume crops such as chickpea is highly hampered by the inherent properties of the soil. It is also unlikely that the current traditional system of cultivation is able to increase yield to the level that is needed to meet the ever-increasing food demand. Therefore, greater technological advances in the areas of crop-soil management practices are highly needed to unlock the genetic potentials of elite cultivars and increase crop yield towards attaining food security in the country. Future research should also address the two critically important physical aspects of the growing media: workability and drainage condition of the Vertisols.

\subsection{Prospects of chickpea cultivation using irrigation}

Chickpea is one of the crops known with low water requirement and has relatively better survival capacity under stress conditions as compared to other food legumes (Vadez et al.
2012). It is, however, important to understand the minimum stress threshold level that the crop can withstand with minimum trade-offs in major economic traits. The flowering and pod setting are the most sensitive growth stages to moisture stress (Nayyar et al. 2005). Number of grains per plant and grain weights is among the key economic traits most affected by moisture stress when occurred at grain filling stage that can cause $50-80 \%$ yield reduction in chickpea (Leport et al. 2006; Nayyar et al. 2005).

Supplemental irrigation can substantially improve yield and attributable traits by overcoming yield reduction caused by terminal drought (Ghassemi-Golezani et al. 2013; Oweis et al. 2004). Dahiya et al. (1993) identified that branching stage and onset of pod formation are the stages at which chickpea attained maximum water consumption. Irrigation at pod formation has increased grain weight and yield of chickpea by about $137 \%$ and $217 \%$, respectively, compared with the rainfed counterparts (Shamsi et al. 2010).

Ethiopia is among the world's drought-prone environments, and terminal drought is one of the major chickpea production bottlenecks in a large part of growing areas. The crop is traditionally planted late on progressively declining soil moisture, and rainfalls often fail to provide enough water that can sustain the crop till maturity. The crop is commonly suffering from drought particularly towards the reproductive phase causing considerable yield losses. The practice of growing chickpea using irrigation in Ethiopia is almost nonexistent. Counting to that, less attention has been given to research and consequently, the development of technologies targeting irrigation farming system is critically limited. Desta et al. (2015) determined water requirement for irrigated chickpea under highland Vertisol production system. According to this report, crop water requirement of chickpea varies greatly depending on the stage of the crop and highly affected by time of seed sowing. Irrigation water demand of chickpea can range between
Fig. 10 Mean grain yield (GY) and biomass yield (BM) of chickpea as affected by time of sowing and seedbed methods studied at two Vertisol on-farm sites over two consecutive seasons. S1 (first sowing date $=$ 16th of August), S2 (second sowing date $=3 \mathrm{rd}$ of September)

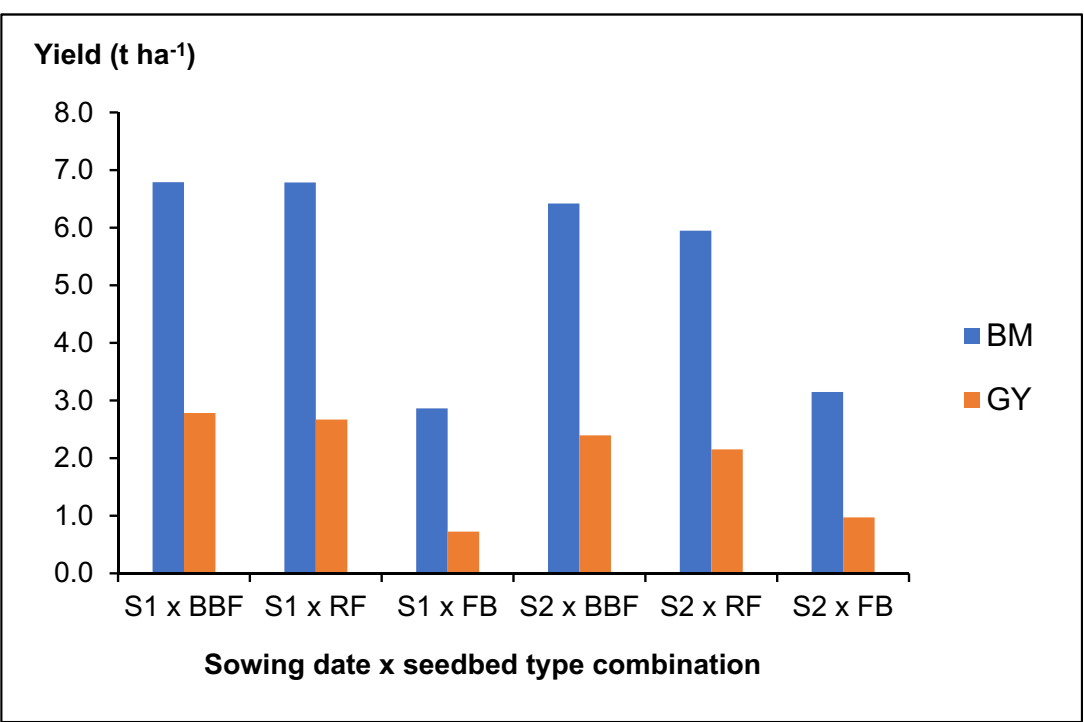


$134 \mathrm{~mm}$ to $437 \mathrm{~mm} \mathrm{ha}^{-1}$ per season under full irrigation production systems (Desta et al. 2015).

Recently, Girma et al. (2017) identified some chickpea genotypes with higher overall agronomic performances and adaptable to irrigation-based production systems. According to this study, the kabuli types showed better response to irrigation compared with the desi types. Interestingly, there was no noticeable alteration in plant phenological traits under irrigated system at all study sites. Mola et al. (2018) also identified elite breeding lines, which combined higher yields and better heat tolerance under lowland irrigated production systems. Contrary to the earlier report by Girma et al. (2017), this study found that the desi types performed better than the kabulis for all agronomic parameters measured under irrigated conditions. Hence, extensive studies covering wider testing sites and growing seasons might be needed to rectify the opposing results. Yet, less efforts have been made in popularizing those promising elite cultivars to the farming community.

In conclusion, supplemental irrigation can augment the traditional rainfed production system and create strong synergy towards enhancing food production in the country. Twice supplementation of rainfed-grown chickpea with irrigation water can be sufficient and economical to stabilize grain yield. This may be of particular importance in view of the current agro-climatic variations which have impacted on many agricultural performances.

\section{Conclusions and future outlook}

In this review, a diligent effort has been made to carefully assess almost all research and development efforts-from the earliest to the present, with special emphasis on aspects of crop management practices underpinning the genetic potential of chickpea in Ethiopia. The role of chickpea in the Ethiopian Vertisol cropping system as a principal rotation crop under the cereal-legume cultivation and in cropping system intensification has been thoroughly discussed. The paper emphasizes that most of the crop management recommendations established for chickpea cultivation are dated long back, and they no more reflect the current agro-climatic setup and environmental changes occurring in due courses. Likewise, many of the recent studies had serious limitations of representing the diverse growing agro-ecologies and farming system dynamism. Therefore, future research should take these limitations into account, and crop management studies should be carried out in a more systematic and coordinated manner covering the wider growing areas.

From this review, it is also evident that there is huge yield gap between the current national average and the attainable yield potential, mainly due to suboptimal management and poor agronomic practices followed by farmers. Therefore, we concluded that yield of Vertisol-grown chickpea is largely constrained by limited use of improved crop management practices, and not by the genetics of the existing cultivars. Reaching the attainable yields of major food security crops $\left(3.5 \mathrm{t} \mathrm{ha}^{-1}\right.$ for chickpea, for instance) by the majority of smallholder farmers has been recognized as the target productivity level of the country's agricultural transformation program. There are strong evidences supporting that greater benefits can be achieved through advanced crop management practices. It is, however, important to underscore that further increases in yield will be more challenging than has been the case for the last two decades if the current "productionas-usual" practice is continuing. This is especially of particular importance in view of the current climate change, a steady increase in human population, the rapid decline of soil fertility, and increasing environmental concerns. We also found strong evidences that best bet agronomic practices of chickpea cultivation should involve early-season sowing, effective surface drainage methods, and optimum application of NPS fertilizers. A synergistic interaction of these key factors resulted in about threefold yield increase compared to the traditional farmers' practices.

Our view here is that the biggest gains from improved Vertisol technology will come most immediately from the integration of improved agronomical practices and highyielding genotypes with appropriate phenology and increased resilience. Furthermore, the following points represent key findings comprehended from this review, where some of the issues may need immediate intervention measures while others identified as future research needs:

1. Past research reports concluded that the application of inorganic fertilizers on chickpea could not have economic returns under the Ethiopian production system. As a consequence, there is a long-standing perception of farmers that chickpea is non-responsive to any kind of fertilizer application, and hence, the crop is commonly cultivated under nutritional stress.

2. Many recent studies, however, have refuted earlier reports and our review confirmed that proper fertilization, specifically NPS, can remarkably increase grain yield and other economic traits in chickpea. It is, however, important to underscore that fertilizer recommendations need to be based on results of soil-test analyses.

3. Our review further verified that crop-soil management aspects of the Vertisol, particularly agronomic requirements, are not yet adequately addressed, which may need research priority.

4. Improved Vertisol management practices and the use of effective surface drainage technologies (e.g., the BBM method) and other novel practices need to be revitalized for chickpea production.

5. There is also a need to develop chickpea cultivars combining high level of tolerance to soil-borne diseases and waterlogging with the help of advanced genetic/genomic tools that can enable early planting under Vertisol production systems. 
Acknowledgments The authors thank Dr. Kebebew Assefa, lead researcher, EIAR/DZARC for editing the manuscript.

Authors' contribution Conceptualization: L.K. and A.F. Methodology: A.F., L.K., B.T., and G.K. Investigation: L.K., B.T., G.K., and T.M. Data acquisition: B.T., T.M., and L.K. Formal analysis: B.T. G.K., and L.K. Writing - original draft, L.K., B.T, G.K., and T.M. Writing-review and editing: A. F. and L.K. Funding acquisition: L.K. and A.F. Resources: A.F., G.K., and T.M. Supervision: A.F., L.K., and G.K.

Funding information The Debre Zeit Agricultural Research Center (DZARC) of the Ethiopian Institute of Agricultural Research (EIAR) and ICRISAT-Ethiopia provided logistic and financial support.

\section{Compliance with ethical standards}

Conflict of interest The authors declare that they have no conflict of interest.

\section{References}

Abdulkadir B, Kassa S, Desalegn T, Tadesse K, Haileselassie M, Fana G, Abera T, Amede T and Tibebe D (2017) Crop response to fertilizer application in Ethiopia: a review. Towards development of site-and context-specific fertilizer recommendation, a working paper. Pp. $21-48$

Abebe M, Mamo T, Duffera M, Kidanu S (1994) Crop response to improved drainage of Vertisols in the Ethiopian highlands. J Agron Crop Sci 172(4):217-222. https://doi.org/10.1111/j.1439-037X. 1994.tb00170.x

Agajie M (2018) Effect of spacing on yield components and yield of chickpea (Cicer arietinum L.) at Assosa, Western Ethiopia. Agric For Fish 7(2):39-51. https://doi.org/10.11648/j.aff.20180702.11

Agegnehu G, Ghizaw A (2004) Effects of drainage and genotype on yield and some yield components faba bean on a highland Vertisol in Ethiopia. Ethiop J Nat Resour 6:167-182

Agegnehu G, Sinebo W (2012) Drainage, sowing date and variety effects on chickpea grown on a Vertisol in Ethiopia. Arch Agron Soil Sci 58(1):10-113. https://doi.org/10.1080/03650340.2010.503958

Agegnehu G, Fikre A and Tadesse A (2006) Cropping systems, soil fertility and crop management research on cool-season food legumes in the central highlands of Ethiopia: a review. In: Ali K, Keneni G, Ahmed S, Malhotra RS, Beniwal S, Makkouk K (eds.) Food and forage legumes of Ethiopia: progress and prospects. Proceedings of the Workshop on Food and Forage Legumes, 2006, Addis Ababa, Ethiopia pp 135-145

Amede T et al. (2002) Biological nitrogen fixation: a key input to integrated soil fertility management in the tropics. Workshop on Biological Nitrogen Fixation for Increased Crop Productivity Enhanced Human Health and Sustained Soil Fertility. Montpellier, France. https://cgspace.cgiar.org/handle/10568/77819. Accessed 7 Jun 2019

Amede T, Descheemaeker K, Mapedza E, Peden D, Breugel P, Awulachew SB, Haileslassie A (2011) Livestock-water productivity in the Nile Basin: solutions for emerging challenges. Nile River Basin Springer, 297-320. DOI:https://doi.org/10.1007/978-94-007-0689-7_15

Anbessa Y, Bejiga G (2002) Evaluation of Ethiopian chickpea landraces for tolerance to drought. Genet Resour Crop Evol 49(6):557-564. https://doi.org/10.1023/A:1021210601480

Asrat A, Tana T and Fikre A (2016) Response of chickpea (Cicer arietinum $L$.) varieties to rates of nitrogen and phosphorus fertilizer at Debre Zeit, Central Ethiopia. In: K., Lijalem et al. (eds.)
Harnessing chickpea value chain for nutrition security and commercialization of smallholder agriculture in Africa. Debre Zeit, Ethiopia. p. $169-183$

Ayana B (2014) Response of chickpea (Cicer arietinum L.) to land preparation methods and sowing dates on Vertisols of southern and southeastern Ethiopia. Int J Agric Sci Res (IJASR) 4(5):17-26

Beck DP (2010) Yield and nitrogen fixation of chickpea cultivars in response to inoculation with selected Rhizobial strains. Agron J 84:510-516. https://doi.org/10.2134/agronj1992.00021962008400030029x

Bejiga G, Tullu A (1982) The influence of planting dates on the yield of three chickpea (Cicer arietinum L.) varieties. Eth J Agric Sci 4(2): $61-66$

Bejiga G, Tullu A, Tsegaye S (1994) Effect of sowing dates and seeding rates on yield and other characteristics of chickpea (Cicer arietinum L.). Eth J Agric Sci 14(1/2):7-14

Bejiga G, Tulu A, Tsegaye S, Eshete M, Anbessa Y (1997) Soil surface drainage and yield of chickpea grown on Vertisols in Ethiopia. Afr Crop Sci J 5(1):23-30. https://doi.org/10.4314/acsj.v5i1.27867

Bekele D, Fikre A, Eshete M, Korbu L, and Girma N (2016) Genetic progresses achieved in Ethiopian chickpea (Cicer arietinum L.) breeding program based on grain yield and seed size. In: K Lijalem et al. (eds.) Harnessing chickpea value chain for nutrition security and commercialization of smallholder agriculture in Africa. Debre Zeit, Ethiopia. p. 119-134

Belayneh H (1986) The effect of drainage systems, drainage spacing and fertilizer on seed yield and other characteristics of wheat, teff and chickpea on heavy clay soils of Ginchi. Ethiop J Agric Sci 8(2):85-94

Beniwal S, Ahmed S, Gorfu D (1992) Wilt/root rot diseases of chickpea in Ethiopia. Trop Pest Manag 38(1):48-51. https://doi.org/10.1080/ 09670879209371644

Beyene S et al. (2015) Guide for chickpea (Cicer arietinum L.) production in the southern nations, nationalities, and peoples' region of Ethiopia. Available at: http://www.usask.ca/food_security ethiopia/. Accessed 24 Jul 2019.

Bezuneh T (1975) Status of chickpea production and research in Ethiopia. In: International Workshop on Grain Legumes, ICRISAT, Hyderabad. p. 95-101

Chala G, Gurmu G, Obsa Z (2018) Organic and inorganic fertilizers application for chickpea (Cicer arietinum L.) production on Vertisols in central highlands of Ethiopia. In: Agegnehu $\mathrm{G}$ et al (eds) Soil fertility and plant nutrient management. EIAR, Addis Ababa, pp 205-215

Clarke N, Bizimana JC, Dile Y, Worqlul A, Osorio J, Herbst B, Richardson JW, Srinivasan R, Gerik TJ, Williams J, Jones CA, Jeong J (2017) Evaluation of new farming technologies in Ethiopia using the integrated decision support system (IDSS). Agric Water Manag 180:267-279. https://doi.org/10.1016/j.agwat. 2016.07.023

CSA (Central Statistics Authority) (1991-2018) Agricultural sample survey: report on area and production of crops, private peasant holdings, Meher Season. Statistical Bulletins, Addis Ababa

CSA (Central Statistics Authority) (2017) Agricultural Sample Survey: Report on Area and Production of Crops, Private Peasant Holdings, Meher Season. Statistical Bulletins, Addis Ababa, Ethiopia.

Dahiya S, Singh M, Singh RB (1993) Economics and water use efficiency of chickpea as effected by genotypes irrigation and fertilizer application. Crop Res Hisar 6:532-534

Das S, Biswas B, Jana K (2016) Effect of farm yard manure, phosphorus and Sulphur on yield parameters, yield, nodulation, nutrient uptake and quality of chickpea (Cicer arietinum L.). J Appl Nat Sci 8(2): 545-549. https://doi.org/10.31018/jans.v8i2.833

Debele T, Deressa H (2016) Integrated management of Vertisols for crop production in Ethiopia: a review. J Biol Agric Healthcare 6(24):26-36

Desta F, Bissa M, Korbu L (2015) Crop water requirement determination of chickpea in the central Vertisol areas of Ethiopia using FAO 
CROPWAT model. Afr J Agric Res 10(7):685-689. https://doi.org/ 10.5897/ajar2014.9084

DZARC (Debre Zeit Agricultural Research Center) (2011) Sequential cropping of annual fodder legume and chickpea on highland Vertisols. Annual Research Report for 2008/09 Cropping Season. pp. $44-54$

Erkossa T, Teklewold H (2009) Agronomic and economic efficiency of manure and urea fertilizers use on Vertisols in Ethiopian highlands. Agric Sci China 8(3):352-360. https://doi.org/10.1016/S16712927(08)60219-9

Erkossa T, Stahr K, Gaiser T (2006) Soil tillage and crop productivity on a Vertisol in Ethiopian highlands. Soil Tillage Res 85(1-2):200-211. https://doi.org/10.1016/j.still.2005.01.009

Esfahani MN, Sulieman S, Schulze J, Yamaguchi-Shinozaki K, Shinozaki K, Tran LS (2014) Approaches for enhancement of $\mathrm{N}_{2}$ fixation efficiency of chickpea (Cicer arietinum L.) under limiting nitrogen conditions. Plant Biotechnol J 12:387-397. https://doi.org/ 10.1111/pbi.12146

Eshete M (1994) Chickpea and lentil agronomy research. In: T., Asfaw et al. (eds.) Cool-season Food Legumes of Ethiopia. p. 230-251

Eshete M, Beniwal S (1987) Chickpea and lentil research in Ethiopia. In: Proceedings of the $19^{\text {th }}$ National Crop Improvement Conference. IAR, Addis Ababa, pp 22-26

Ethiopian Soil Information System (EthioSIS) (2014) Soil analysis report. Agricultural Transformation Agency (ATA), Addis Ababa Available at: http:/www.ata.gov.et/programs/highlighted-deliverables/ethiosis/. Accessed 25 Oct 2019.

Evans J (1982) Symbiosis nitrogen and dry matter distribution in chickpea (Cicer arietinum L.). Exp Agric 18(4):339-351. https://doi.org/ 10.1017/S0014479700000764

FAOSTAT (2016) FAO (Food and Agriculture Organization of the United Nations), Rome. Available at: http://www.fao.org/statistics/en/. Accessed 3 May 2018

Ferede S, Fikre A, Ahmed S (2018) Assessing the competitiveness of smallholders chickpea production in the central highlands of Ethiopia. Ethiop J Crop Sci 6(2):51-65

Fikre A (2016) Unraveling valuable traits in Ethiopian grain legumes research hastens crop intensification and economic gains: a review. Univ J Agric Res 4(5):175-182. https://doi.org/10.13189/ujar.2016.040503

Fikre A, Funga A, Korbu L, Eshete M, Girma N (2018) Stability analysis in chickpea genotype sets as tool for breeding germplasm structuring strategy and adaptability scoping. Ethiop J Crop Sci 6(2):19-37

Ghassemi-Golezani K, Ghassemi S, Bandehhagh A (2013) Effects of water supply on field performance of chickpea (Cicer arietinum L.) cultivars. Intl J Agron Plant Prod 4(4):94-97

Girma N, Fikre A, Ojiewo C (2017) The genotypic and phenotypic basis of chickpea (Cicer arietinum L.) cultivars for irrigation-based production in Ethiopia. J Agric Sci 9(8):229-236. https://doi.org/10. 5539/jas.v9n8p229

Goud V, Konde N, Mohod P, Kharche V (2014) Response of chickpea to potassium fertilization on yield, quality, soil fertility and economic in Vertisols. Legum Res 37(3):311-315. https://doi.org/10.5958/j. 0976-0571.37.3.047

Hailu H, Mamo T, Keskinen R, Karltun E, Gebrekidan H, Bekele T (2015) Soil fertility status and wheat nutrient content in Vertisol cropping systems of central highlands of Ethiopia. Agric Food Secur 4(1):4-19. https://doi.org/10.1186/s40066-015-0038-0

Headey D, Dereje M, Taffesse A (2014) Land constraints and agricultural intensification in Ethiopia: a village-level analysis of high-potential areas. Food Policy 48:129-141. https://doi.org/10.1016/j.foodpol. 2014.01.008

Hoogenboom G et al (2010) Decision support system for agrotechnology transfer (DSSAT) version 4.5 [CD ROM]. University of Hawaii, Honolulu
Hussen S, Yirga F, Tibebu F (2013) Effect of phosphorus fertilizer on yield and yield components of chickpea (Cicer arietinum) at Kelem Meda, south Wollo, Ethiopia. Int J Soil Crop Sci 1(1):1-4

ILRI (2015) Public-private partnerships (PPPs) for sustainable input business: the Case of Menagesha biotech industry in Ethiopia. Available at: http://n2africa.org/. Accessed 13 Jun 2019.

ILRI (2018) Africa research in sustainable intensification for the next generation Ethiopian highlands project technical report, 1 April-30 September 2018. Nairobi, Kenya; ILRI. Available at: www.africarising.net/. Accessed 13 Jun 2019

Jemberu T et al (2018) Agronomic and economic evaluation of wheatchickpea double cropping on the Vertisol of Takusa, North Western Ethiopia. Ethiop J Crop Sci 6(2):67-78

Jukanti A, Gaur PM, Gowda CLL, Chibbar R (2012) Nutritional quality and health benefits of chickpea (Cicer arietinum L.): a review. Br J Nutr 108(S1):S11-S26. https://doi.org/10.1017/S0007114512000797

Jutzi S and Abebe M (1987) Improved agricultural utilization of Vertisols in the Ethiopian highlands - an interinstitutional approach. In: Proceedings of the First Regional Seminar on Management of Vertisols Under Semi-arid Conditions, Nairobi, Kenya. p. 173-183

Kahurananga J, Tsehay A (1984) Preliminary assessment of some annual Ethiopian Trifolium species for hey production. Tropical Grasslands 18(4):215-217 https://hdl.handle.net/10568/27931. Accessed 15 Aug 2019

Kanwar JS, Kampen J, and Virmani S (1982) Management of Vertisols for maximising crop production- ICRISAT experience: proceedings of an IBSRAM Inaugural Workshop, ICRISAT, Lndia. (1): P. 157172. http://oar.icrisat.org/4045/1/cp 52.pdf. Accessed 21 Jun 2019.

Keneni $G$ et al (2012) Phenotypic diversity for symbio-agronomic characters in Ethiopian chickpea (C. arietinum L.) germplasm accessions. Afr J Biotechnol 11(63):12634-12651. https://doi.org/10. 5897/ajb12.428

Korbu L, Girma N, Fikre A and Angassa D (2016) The role of international research collaboration in broadening genetic base of chickpea in Ethiopia: implications on local germplasm use. In: K., Lijalem et al. (eds.) Harnessing chickpea value chain for nutrition security and commercialization of smallholder agriculture in Africa. Debre Zeit, Ethiopia. p. 146-162

Kumar R, Wani SP and Lee KK (1996) Biological nitrogen fixation. In: Dynamics of roots and nitrogen in cropping systems of the SAT. Proceedings of the International Workshop, JIRCAS International Agriculture Series No. 3. P. 322-334

Leport L, Turner NC, Davies SL, Siddique KHM (2006) Variation in pod production and abortion among chickpea cultivars under terminal drought. Eur J Agron 24(3):236-246. https://doi.org/10.1016/j.eja. 2005.08.005

LUPRD (Land Use Planning and Regulatory Department) (1984) Provisional soil association MAP of Ethiopia $(1: 2,000.000)$. LUPRD/(MoA)/UNDP/FAO, Addis Ababa

Mamo T and Dibabe A (1994) Soil microbiology research. In: Asfaw T, Geletu B, Saxena MC and Solh MB (eds.) Cool-season Food Legumes of Ethiopia. P. 293-311

Mamo T, Astatke A, Srivastava KL and Dibabe A (eds.) (1993) Improved management of Vertisols for sustainable crop-livestock production in the Ethiopian highlands; Synthesis report, 1986-1992, Addis Ababa

Mamo T, Abebe M, Duffera M, Kidanu S, Erkosa T (1994) Response of chickpea to method of seed bed preparation and phosphorus application on Ethiopian Vertisols. Int Chickpea and Pigeonpea Newslett 1(1):17-18

Mamo T, Richter C, Heiligtag B (2002) Phosphorus availability studies on ten Ethiopian Vertisols. J Agric Rural Dev Trop Subtrop 103(2): 177-183 ISSN: 16129830

Minta M, Assefa G, Feyissa F (2014) Potential of feed-food doublecropping in central highlands of Ethiopia. Arch Agron Soil Sci 60(9):1249-1260. https://doi.org/10.1080/03650340.2013.878456 
Mohammed A, Tana T, Singh P, Korecha D, Molla A (2017) Management options for rainfed chickpea (Cicer arietinum L.) in Northeast Ethiopia under climate change condition. Clim Risk Manag 16:222-233. https://doi.org/10.1016/j.crm.2016.12.003

Mola T, Alemayehu S, Fikre A, Ojiewo C et al (2018) Heat tolerance responses of chickpea (Cicer arietinum L.) genotypes in the thermal zone of Ethiopia, a case of Werer station. Ethiop J Crop Sci 6(2):95-118

Morton J (2007) The impact of climate change on smallholder and subsistence agriculture. Proc Natl Acad Sci USA 104(50):1968019685. https://doi.org/10.1073/pnas.0701855104

Murray J, Liu C, Chen Y, Miller A (2017) Nitrogen sensing in legumes. J Exp Bot 68(8):1919-1926. https://doi.org/10.1093/jxb/erw405

Nayyar H, Kaur S, Smita K, Singh J, Dhir KK, Bains T (2005) Water stress-induced injury to reproductive phase in chickpea: evaluation of stress sensitivity in wild and cultivated species in relation to abscisic acid and polyamines. J Agron Crop Sci 191(6):450-457. https://doi.org/10.1111/j.1439-037X.2005.00184.x

Nigussie D (2018) GIS-based land suitability mapping for legume crops technology targeting and scaling-up. Ethiop J Crop Sci (Special issue) 6(3):180-198

Oweis T, Hachum A, Pala M (2004) Water use efficiency of winter-sown chickpea under supplemental irrigation in a Mediterranean environment. Agric Water Manag 66:163-179

Pang J et al (2017) Response of chickpea (Cicer arietinum L.) to terminal drought: leaf stomatal conductance, pod abscisic acid concentration, and seed set. J Exp Bot 68(8):1973-1985. https://doi.org/10.1093/ jxb/erw153

Peña TC, Pueyo JJ (2012) Legumes in the reclamation of marginal soils, from cultivar and inoculant selection to transgenic approaches. Agron Sustain Dev 32:65-91. https://doi.org/10.1007/s13593-011-0024-2

Peoples MB, Craswell ET (1992) Biological nitrogen fixation: investments, expectations and actual contributions to agriculture. Plant Soil 141(1):13-39. https://doi.org/10.1007/BF00011308

Robson A, O'Hara G, Abbott L (2006) Involvement of phosphorus in nitrogen fixation by subterranean clover (Trifolium subterraneum L.). Funct Plant Biol 8(5):427-436. https://doi.org/10.1071/ pp9810427

Saeed M, Akram HM, Iqbal MS, Yar A, Ali A (2004) Impact of fertilizer on seed yield of chickpea genotypes. Int J Agric Biol 6(1):108-109

Saxena MC (1980) Recent advances in chickpea agronomy. In: Proceedings of the international Workshop on Chickpea Improvement. International Crops Research Institute for the SemiArid Tropics (ICRISAT). Patancheru, India, pp 89-96

Schlecht E, Buerkert A, Tielkes E, Bationo A (2006) A critical analysis of challenges and opportunities for soil fertility restoration in SudanoSahelian West Africa. Nutr Cycl Agroecosyst 76(2-3):109-136. https://doi.org/10.1007/s10705-005-1670-z

Shah T, Fareed A, Nauman M (2016) Yield and quality response of chickpea cultivars to different NPK levels. Austin Food Sci 1(4): $1-4$

Shamsi K, Kobraee S, Haghparast R (2010) Drought stress mitigation using supplemental irrigation in rainfed chickpea (Cicer arietinum L.) varieties in Kermanshah, Iran. Afr J Biotechnol 9(27):41974203. https://doi.org/10.5897/AJB09.1843

Shewangizaw B, Argaw A, Feyisa T, Wold-meskel E, and Abdulkadir B (2019) Response of chickpea (Cicer aritienum L.) to sulphur and zinc nutrients application and rhizobium inoculation in north western Ethiopia.. Agronomy, 1-19. https://doi.org/10.21203/rs.2. $18531 / \mathrm{v} 1$
Shiferaw M, Tana T, Fikre A (2018) Effect of plant density on yield components and yield of Kabuli chickpea (Cicer arietinum L.) varieties at Debre Zeit, Central Ethiopia. Int J Plant Soil Sci 21(6): 1-6. https://doi.org/10.9734/ijpss/2018/19120

Singh S, Singh I, Kapoor K, Gaur PM, Chaturvedi SK, Singh NP and Sandhu JS (2014) Broadening the genetic base of grain legumes. In: Singh M et al. (eds.) pp. 51-74. DOI: https://doi.org/10.1007/97881-322-2023-7

Snapp S, Rahmanian M and Batello C (2018) Pulse crops for sustainable farms in sub-Saharan Africa. In: T. Calles (ed.) Rome, FAO. Available at: http://www.fao.org/publications/card/en/c/I8300EN. Accessed on 5 Jul 2019.

Tadele Z (1994) Tef in the farming Systems of the Ada Area. Research report no. 24. Institute of Agricultural Research (IAR), Addis Ababa. pp. 26. http://hdl.handle.net/10568/82996. Accessed 9 Jun 2019

Tamene L, Amede T, Kihara J, Tibebe D and Schulz S (eds.) (2017) A review of soil fertility management and crop response to fertilizer application in Ethiopia: towards development of site- and contextspecific fertilizer recommendation. CIAT publication no. 443. Addis Ababa. p. 86. Available at: http://hdl.handle.net/10568/82996. Accessed 12 Oct 2019

Tebkew D, Ojiewo C (2016) Current status of wilt/root rot diseases in major chickpea growing areas of Ethiopia. Arch Phytopathol Plant Protect. https://doi.org/10.1080/03235408.2016.1180925.

Vadez V et al (2012) Adaptation of grain legumes to climate change: a review. Agron Sustain Dev 32(1):31-44. https://doi.org/10.1007/ s13593-011-0020-6

Vanlauwe B et al (2014) Sustainable intensification and the African smallholder farmer. Curr Opin Environ Sustain 8:15-22. https:// doi.org/10.1016/j.cosust.2014.06.001

Verkaart S, Munyua BG, Mausch K, Michler JD (2017) Welfare impacts of improved chickpea adoption: a pathway for rural development in Ethiopia? Food Policy 66:50-61. https://doi.org/10.1016/j.foodpol. 2016.11.007

Verma VK, Pandya KS (2003) Response of rainfed chickpea to NPK fertilizer and its economics in light textured soils. Adv Plant Sci 6: $181-185$

Wakeel AE, Astatke A (1996) Intensification of agriculture on Vertisols to minimize land degradation in parts of the Ethiopian highlands. Land Degrad Dev 7(1):57-67. https://doi.org/10.1002/(SICI)1099145X(199603)7

Wolde-meskel E et al (2018) Additive yield response of chickpea (Cicer arietinum L.) to rhizobium inoculation and phosphorus fertilizer across smallholder farms in Ethiopia. Agric Ecosyst Environ 261: 144-152. https://doi.org/10.1016/j.agee.2018.01.035

Woldesenbet L, Haile W, Beyene S (2013) Response of chickpea (Cicer arietinum L.) to nitrogen and phosphorus fertilizers in Halaba and Taba, southern Ethiopia. Ethiop J Nat Resour 13(2):115-128

Wubetu A (2017) A review on Vertisol management, challenges and future potential for food self- sufficiency in Ethiopia. J Biol Agriculture and Healthcare 7(17):115-127

Yimer S, Ahmed S, Fininsa C, Tadesse N, Hamwieh A, Cook DR (2018) Distribution and factors influencing chickpea wilt and root rot epidemics in Ethiopia. Crop Prot 106:150-155. https://doi.org/10. 1016/j.cropro.2017.12.027

Publisher's note Springer Nature remains neutral with regard to jurisdictional claims in published maps and institutional affiliations. 